Article

\title{
Novel Oleanane-Type Triterpene Glycosides from the Saponaria officinalis L. Seeds and Apoptosis-Inducing Activity via Mitochondria
}

\author{
Naoki Takahashi, Tomoki Iguchi *, Minpei Kuroda, Masaki Mishima and Yoshihiro Mimaki
}

check for updates

Citation: Takahashi, N.; Iguchi, T.; Kuroda, M.; Mishima, M.; Mimaki, Y. Novel Oleanane-Type Triterpene Glycosides from the Saponaria officinalis L. Seeds and

Apoptosis-Inducing Activity via Mitochondria. Int. J. Mol. Sci. 2022, 23, 2047. https://doi.org/10.3390/ ijms23042047

Academic Editor: Luciano Saso

Received: 25 January 2022

Accepted: 8 February 2022

Published: 12 February 2022

Publisher's Note: MDPI stays neutral with regard to jurisdictional claims in published maps and institutional affiliations.

Copyright: (C) 2022 by the authors. Licensee MDPI, Basel, Switzerland. This article is an open access article distributed under the terms and conditions of the Creative Commons Attribution (CC BY) license (https:// creativecommons.org/licenses/by/ $4.0 /)$.
School of Pharmacy, Tokyo University of Pharmacy and Life Sciences, 1432-1, Horinouchi, Hachioji, Tokyo 192-0392, Japan; y20612@toyaku.ac.jp (N.T.); kurodam@toyaku.ac.jp (M.K.); mmisima@toyaku.ac.jp (M.M.); mimakiy@toyaku.ac.jp (Y.M.)

* Correspondence: iguchit@toyaku.ac.jp; Tel.: +81-42-676-4575

\begin{abstract}
Saponaria officinalis L., commonly known as "Soapwort", is a rich source of triterpene glycosides; however, the chemical constituents of S. officinalis seeds have not been fully identified. In this study, we conducted a systematic phytochemical investigation of the seeds of $S$. officinalis and obtained 17 oleanane-type triterpene glycosides (1-17), including seven new glycosides (1-7). The structures of 1-7 were determined based on a detailed analysis of NMR spectroscopic data and chromatographic and spectroscopic analyses following specific chemical transformation. The cytotoxicities of the isolated compounds were evaluated against HL-60 human promyelocytic leukemia cells, A549 human adenocarcinoma lung cancer cells, and SBC-3 human small-cell lung cancer cells. The cytotoxicities of 1, 4, and 10 toward HL-60 cells and SBC-3 cells were nearly as potent as that of cisplatin. Compound 1, a bisdesmosidic triterpene glycoside obtained in good yield, arrested the cell cycle of SBC-3 cells at the $\mathrm{G}_{2} / \mathrm{M}$ phase, and induced apoptosis through an intrinsic pathway, accompanied by ROS generation. As a result of the mitochondrial dysfunction induced by $\mathbf{1}$, mitochondria selective autophagy, termed mitophagy, occurred in SBC-3 cells.
\end{abstract}

Keywords: Saponaria officinalis; Caryophyllaceae; seed; triterpene glycoside; cytotoxicity; apoptosis; mitophagy; HL-60 cell; A549 cell; SBC-3 cell

\section{Introduction}

During our ongoing phytochemical investigations of higher plants with a focus on new cytotoxic constituents, we have isolated cytotoxic triterpene glycosides from Dolichos lablab [1], Stryphnodendron fissuratum [2], Eranthis cilicica [3], Larrea tridentata [4], Anemone hupehensis var. japonica [5], Caulophyllum thalictroides [6], and Clematis chinensis [7]. The genus Saponaria (Caryophyllaceae) includes approximately 30 species with distribution in Europe and western Asia. Saponaria officinalis L., commonly known as "Soapwort", is a perennial plant and is now cultivated mainly for ornamental purpose. Radix Saponariae, the dried roots of $S$. officinalis, has been used as a folk medicine for expectorant, syphilis, skin complaints, and rheumatic disorders [8-10]. Previous phytochemical investigations of S. officinalis resulted in the isolation of highly polar triterpene glycosides, the sugar moieties of which comprise 3-10 monosaccharides [11-16], indicating that S. officinalis is a rich source of triterpene glycosides. However, a literature survey indicated that a systematic phytochemical examination of the seeds of $S$. officinalis has not yet been conducted.

In the statistical data for the ten-year relative survival of Japanese cancer patients between 2002 and 2006, the survival rates of lung cancer and leukemia patients were $18.1 \%$ and $20.5 \%$ for males (aged 15 to 99 ), and $31.2 \%$ and $20.5 \%$ for females (aged 15 to 99), respectively [17]. Although lung cancer and leukemia patients successfully go into remission, they are not satisfied with current long-term medical treatment owing to relatively high-frequency recurrence. Small-cell lung cancer is generally treated with 
cisplatin, etoposide, irinotecan, paclitaxel, and vincristine, while few molecularly targeted drugs or immune checkpoint inhibitors have been approved. The above anticancer agents frequently cause severe undesirable side effects such as myelosuppression, vomit, acute kidney injury, peripheral neuropathy, hepatic dysfunction, and diarrhea, which deterrent the quality of life of patients. Thus, the development of new anticancer agents is expected to improve the survival rates of cancer patients and reduce undesirable side effects.

In our phytochemical investigation of $S$. officinalis seeds, we focused on triterpene glycosides and isolated 17 glycosides (1-17), including seven new ones (1-7). The structures of 1-7 were elucidated based on extensive analyses of NMR spectroscopic data, and chromatographic and spectroscopic analyses following chemical transformations. The cytotoxic activities of the isolated compounds were examined against HL-60 human promyelocytic leukemia cells, A549 human adenocarcinoma lung cancer cells, and SBC-3 human small-cell lung cancer cells. Furthermore, the apoptosis-inducing activity of $\mathbf{1}$ in SBC-3 cells was evaluated.

\section{Results and Discussion}

\subsection{Structure Characterization of $\mathbf{1 - 1 7}$}

The seeds of $S$. officinalis $(1.0 \mathrm{~kg})$ were extracted using $\mathrm{MeOH}\left(60^{\circ} \mathrm{C}\right)$, and then the solvent was removed under reduced pressure. The $\mathrm{MeOH}$ extract (50 g) was subjected to silica gel and octadecylsilanized (ODS) silica gel column chromatography (CC), and preparative ODS high-performance liquid chromatography (HPLC) to obtain 17 compounds (1-17) (Figure 1). Compounds 8-17 were identified as $3 \beta-[(O-\beta$-D-galactopyranosyl- $(1 \rightarrow 2)-O-[\beta-D-x y l o p y r a n o s y l-$ $(1 \rightarrow 3)$ ]- $\beta$-D-glucuronopyranosyl)oxy]-16 $\alpha$-hydroxy-23-oxo-olean-12-en-28-oic acid (8) [18], 3 3 [(O- $\beta$-D-galactopyranosyl-( $1 \rightarrow 2)-O-[\beta$-D-xylopyranosyl-( $1 \rightarrow 3)]-\beta$-D-glucuronopyranosyl)oxy]$16 \alpha$-hydroxy-23-oxo-olean-12-en-28-oic acid $O$ - $\beta$-D-xylopyranosyl- $(1 \rightarrow 4)-O$ - $\alpha$-L-rhamnopyra nosyl-(1 $\rightarrow 2)-O-[\alpha$-L-rhamnopyranosyl- $(1 \rightarrow 3)]-4-O-a c e t y l-\beta$-D-fucopyranosyl ester (9) [19], $3 \beta$ [(O- $\beta$-D-galactopyranosyl-( $1 \rightarrow 2)-O-[\beta$-D-xylopyranosyl-( $1 \rightarrow 3)]-\beta$-D-glucuronopyranosyl)oxy]$16 \alpha$-hydroxy-23-oxo-olean-12-en-28-oic acid $O-\beta$-D-xylopyranosyl- $(1 \rightarrow 3)-O-\beta$-D-xylopyranosyl$(1 \rightarrow 4)-O-\alpha$-L-rhamnopyranosyl- $(1 \rightarrow 2)-O-[4-O$-acetyl- $\beta$-D-quinovopyranosyl- $(1 \rightarrow 4)]-\beta$-D-fuco pyranosyl ester (saponarioside B) (10) [16], 3 $\beta$-hydroxyolean-12-en-23,28-dioic acid 28-O- $\beta$-Dglucopyranosyl- $(1 \rightarrow 2)-O-\beta$-D-galactopyranosyl- $(1 \rightarrow 3)-O-[\beta$-D-glucopyranosyl- $(1 \rightarrow 6)]-\beta-\mathrm{D}-\mathrm{g}$ alactopyranosyl ester (11) [20], 3 $\beta$-hydroxyolean-12-en-23,28-dioic acid 28-O- $\beta$-D-glucopyranosyl$(1 \rightarrow 2)-O-\beta$-D-glucopyranosyl-( $1 \rightarrow 6)-O-[\beta$-D-glucopyranosyl- $(1 \rightarrow 3)]-\beta$-D-glucopyranosyl ester (vaccaroid A) (12) [21], 3 $\beta$-hydroxyolean-12-en-23,28-dioic acid 28-O- $\beta$-D-glucopyranosyl- $(1 \rightarrow 2)$ $O-(6-O-(3-h y d r o x y-3-m e t h y l g l u t a r y l)-\beta$-D-glucopyranosyl)-( $1 \rightarrow 6)-O-[\beta-D-g l u c o p y r a n o s y l-(1 \rightarrow 3)]-$ $\beta$-D-glucopyranosyl ester (vaccaroside B) (13) [22], 3 $\beta, 16 \alpha$-dihydroxyolean-12-en-23,28-dioic acid 28-O- $\beta$-D-glucopyranosyl-( $1 \rightarrow 2)-O-\beta$-D-glucopyranosyl- $(1 \rightarrow 6)-O-[\beta$-D-glucopyranosyl$(1 \rightarrow 3)]-\beta$-D-glucopyranosyl ester (segetoside K) (14) [23], 3 $\beta$-[( $\beta$-D-xylopyranosyl)oxy]-olean-12en-23,28-dioic acid 28-O- $\beta$-D-glucopyranosyl- $(1 \rightarrow 2)-O-\beta$-D-glucopyranosyl- $(1 \rightarrow 6)-\beta$-D-glucopyr anosyl ester (saponarioside M) (15) [14], 3 $\beta$-[( $\beta$-D-xylopyranosyl)oxy]-olean-12-en-23,28-dioic acid 28-O- $\beta$-D-glucopyranosyl- $(1 \rightarrow 2)-O-\beta$-D-glucopyranosyl- $(1 \rightarrow 6)-O-[\beta$-D-glucopyranosyl$(1 \rightarrow 3)]-\beta$-D-glucopyranosyl ester (saponarioside D) (16) [15], and 16 $\alpha$-hydroxy-3 $\beta$-[( $\beta$-D-xylopyr anosyl)oxy]olean-12-en-23,28-dioic acid 28-O- $\beta$-D-glucopyranosyl-(1 $\rightarrow 2)-O$ - $\beta$-D-glucopyranosyl$(1 \rightarrow 6)-O-[\beta$-D-glucopyranosyl- $(1 \rightarrow 3)]-\beta$-D-glucopyranosyl ester (saponarioside F) (17) [15], respectively. 

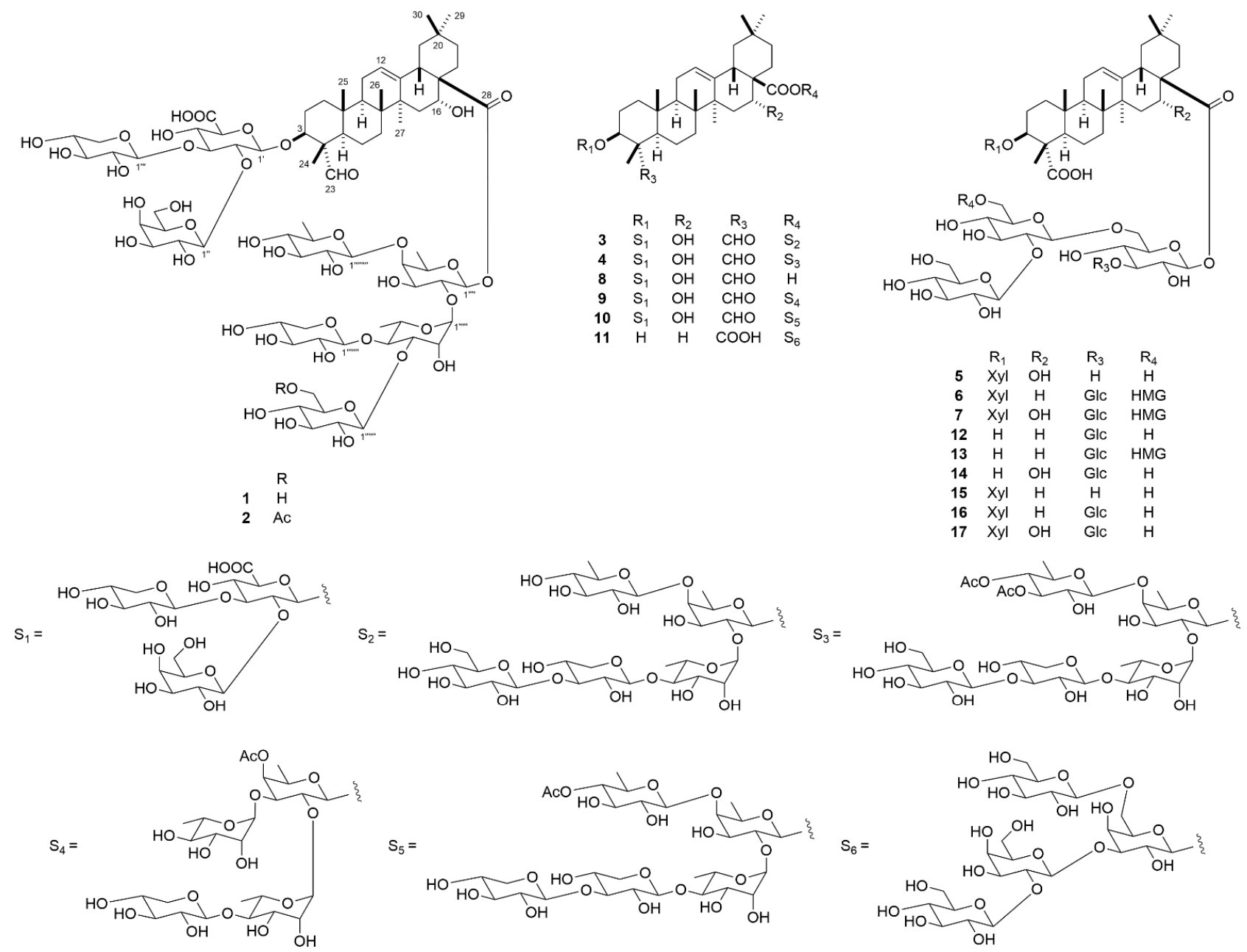

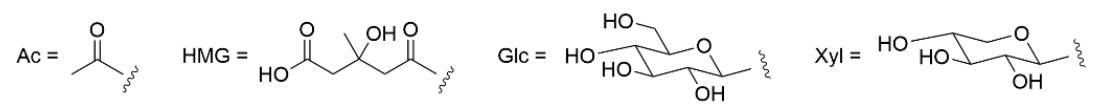

Figure 1. Structures of 1-17. Compounds 1-7, 9, 10, 15-17 are bisdesmosidic triterpene glycosides, among which 1-7 are previously undescribed.

Compound 1 was obtained as an amorphous solid, and its molecular formula was assigned as $\mathrm{C}_{76} \mathrm{H}_{120} \mathrm{O}_{41}$ based on the accurate sodium adduct ion at $m / z 1711.7161$ [M $+\mathrm{Na}]^{+}$(calculated for $\mathrm{C}_{76} \mathrm{H}_{120} \mathrm{NaO}_{41}: 1711.7203$ ) using high-resolution electrospray ionization time-of-flight mass spectroscopy (HR-ESI-TOF-MS) and ${ }^{13} \mathrm{C}-\mathrm{NMR}$ spectral data. In the ${ }^{1} \mathrm{H}$ - and ${ }^{13} \mathrm{C}-\mathrm{NMR}$ spectra of $\mathbf{1}$, the following signals were observed: six tertiary methyl groups [ $\delta_{\mathrm{H}} 1.73(\mathrm{~s}, \mathrm{Me}-27), 1.46$ (s, Me-24), 1.10 (s, Me-26), 0.93 (s, Me-30), 0.92 (s, Me-29), and 0.84 (s, Me-25); $\delta_{C} 33.1$ (C-29), 27.1 (C-27), 24.4 (C-30), 17.4 (C-26), 15.9 (C-25), and $11.1(\mathrm{C}-24)]$, two oxygenated methine groups [ $\delta_{\mathrm{H}} 5.11(\mathrm{br} \mathrm{s}, \mathrm{H}-16)$ and $4.06(\mathrm{~m}, \mathrm{H}-3)$; $\delta_{\mathrm{C}} 84.4(\mathrm{C}-3)$ and $\left.74.2(\mathrm{C}-16)\right]$, an olefinic group [ $\delta_{\mathrm{H}} 5.50(\mathrm{~m}, \mathrm{H}-12) ; \delta_{\mathrm{C}} 144.5(\mathrm{C}-13)$ and $121.9(\mathrm{C}-12)]$, an aldehyde group $\left[\delta_{\mathrm{H}} 9.91(\mathrm{~s}, \mathrm{H}-23) ; \delta_{\mathrm{C}} 210.1(\mathrm{C}-23)\right]$, an ester carbonyl carbon $\left[\delta_{C} 175.9(\mathrm{C}-28)\right]$, six quaternary carbons $\left[\delta_{C} 55.0(\mathrm{C}-4), 49.2(\mathrm{C}-17), 42.1(\mathrm{C}-14)\right.$, $40.3(\mathrm{C}-8), 36.2(\mathrm{C}-10)$, and $30.6(\mathrm{C}-20)]$, and eight anomeric protons/carbons $\left[\delta_{\mathrm{H}} 6.00(\mathrm{br}\right.$ s), $5.88(\mathrm{~d}, J=8.2 \mathrm{~Hz}), 5.54(\mathrm{~d}, J=7.7 \mathrm{~Hz}), 5.50(\mathrm{~d}, J=7.9 \mathrm{~Hz}), 5.39(\mathrm{~d}, J=7.7 \mathrm{~Hz}), 5.31$ $(\mathrm{d}, J=7.7 \mathrm{~Hz}), 4.98(\mathrm{~d}, J=7.9 \mathrm{~Hz})$, and $4.89(\mathrm{~d}, J=7.8 \mathrm{~Hz}) ; \delta_{\mathrm{C}} 106.3,105.2,105.0,104.9$, 104.2, 103.9, 101.7, and 94.8]. Treatment of 1 with $1 \mathrm{M} \mathrm{KOH}$ in $\mathrm{MeOH}$ yielded 8 and the sugar fraction, and subsequent acid hydrolysis of the sugar fraction using $1 \mathrm{M} \mathrm{HCl}$ in 1,4-dioxane $/ \mathrm{H}_{2} \mathrm{O}(1: 1)$ afforded D-fucose, D-glucose, D-quinovose, L-rhamnose, and D-xylose. The monosaccharides were identified based on HPLC analysis using a combi- 
nation of optical rotation and refractive index detectors. As the sugar moieties of $\mathbf{1}$ were composed of eight monosaccharides, their numerous proton signals overlapped severely, precluding their assignment using conventional NMR analysis. To address this issue, onedimensional total correlation spectroscopy (1D-TOCSY) and heteronuclear single quantum coherence (HSQC)-TOCSY spectroscopy in addition to ${ }^{1} \mathrm{H}-{ }^{1} \mathrm{H}$ correlation spectroscopy (COSY) and HSQC spectroscopy were applied. The ${ }^{1} \mathrm{H}-\mathrm{NMR}$ subspectra of individual glycosyl units were obtained by selective irradiation of each anomeric proton signal and other non-overlapping proton signals. Subsequent analysis of the ${ }^{1} \mathrm{H}-{ }^{1} \mathrm{H}$ COSY spectrum allowed for the sequential assignment of the proton resonances for the pentaglycosyl moiety attached to $\mathrm{C}-28$ of the aglycone, enabling us to identify their multiplet patterns and coupling constants. The HSQC and HSQC-TOCSY spectra correlated the proton signals with the corresponding one-bond-coupled carbon shifts. The assigned ${ }^{1} \mathrm{H}$ - and ${ }^{13} \mathrm{C}-\mathrm{NMR}$ signals indicated that the C-28 pentaglycosyl moiety consisted of a 2,4-disubstituted $\beta$-Dfucopyranosyl unit [Fuc: $\delta_{\mathrm{H}} 5.88\left(\mathrm{~d}, J=8.2 \mathrm{~Hz}, \mathrm{H}-1^{\prime \prime \prime}\right.$ of Fuc); $\delta_{\mathrm{C}} 94.8,75.2,75.9,83.4,71.5$, and 17.1 (C-1"'"-C-6"'" of Fuc)], a 3,4-disubstituted $\alpha$-L-rhamnopyranosyl unit [Rha: $\delta_{\mathrm{H}}$ 6.00 (br s, H-1"'"' of Rha); $\delta_{C} 101.7,70.8,82.3,78.2,68.9$, and 18.9 (C-1"'"'-C-6"'"' of Rha)], a terminal $\beta$-D-glucopyranosyl unit [Glc: $\delta_{\mathrm{H}} 5.39$ (d, J = 7.7 Hz, H-1"'"'” of Glc); $\delta_{\mathrm{C}} 105.2,75.4$, 78.3, 71.7, 78.4, and 62.6 (C-1"'"'"-C-6"'"'" of Glc)], a terminal $\beta$-D-xylopyranosyl unit [Xyl (II): $\delta_{\mathrm{H}} 5.50\left(\mathrm{~d}, J=7.9 \mathrm{~Hz}, \mathrm{H}-1^{\prime \prime \prime \prime \prime \prime \prime \prime ~ o f ~} \mathrm{Xyl}(\mathrm{II})\right) ; \delta_{\mathrm{C}} 104.9,75.6,79.1,71.2$, and 67.1 (C-1"'"'"'-C$\left.\left.5^{\prime \prime \prime \prime \prime \prime \prime ~ o f ~} \mathrm{Xyl}(\mathrm{II})\right)\right]$, and a terminal $\beta$-D-quinovopyranosyl unit [Qui: $\delta_{\mathrm{H}} 4.98(\mathrm{~d}, J=7.9 \mathrm{~Hz}$,

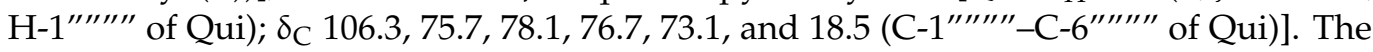
$\beta$-orientations of the anomeric centers of Fuc, Glc, Xyl, and Qui were determined based on the relatively large ${ }^{3} J_{\mathrm{H}-1, \mathrm{H}-2}$ values. The large ${ }^{1} J_{\mathrm{H}-1, \mathrm{C}-1}$ value $(171 \mathrm{~Hz})$ of Rha suggested that the anomeric configuration of Rha was $\alpha$-oriented [16]. In the heteronuclear multiple bond correlation (HMBC) spectrum of $1,{ }^{3} J_{\mathrm{C}, \mathrm{H}}$ correlations were observed between $\mathrm{H}-1^{\prime \prime \prime \prime \prime \prime}$ of Glc and C-3"'"' of Rha, H-1"'"'"' of Xyl (II) and C-4"'"' of Rha, H-1"'"' of Rha and C-2"'" of Fuc, H-1"'"'"' of Qui and C-4"'" of Fuc, and between $\mathrm{H}-1$ "'" of Fuc and C-28 of the aglycone. Thus, 1 was determined to be $3 \beta-[(O-\beta$-D-galactopyranosyl- $(1 \rightarrow 2)-O-[\beta-D-x y l o p y r a n o s y l-$ $(1 \rightarrow 3)]$ - $\beta$-D-glucuronopyranosyl)oxy]-16 $\alpha$-hydroxy-23-oxo-olean-12-en-28-oic acid O- $\beta$-Dglucopyranosyl- $(1 \rightarrow 3)-O$-[ $\beta$-D-xylopyranosyl- $(1 \rightarrow 4)]-O-\alpha$-L-rhamnopyranosyl- $(1 \rightarrow 2)-O$ - $[\beta$ D-quinovopyranosyl-( $1 \rightarrow 4)$ ]- $\beta$-D-fucopyranosyl ester. Although $\mathbf{1}$ has been described as a possible putative model compound of cell-targeting binding molecules in a patent [24], this is the first time it has been isolated from a natural source and its structure determined based on extensive NMR spectroscopic data.

The ${ }^{1} \mathrm{H}$ - and ${ }^{13} \mathrm{C}-\mathrm{NMR}$ spectra of $2\left(\mathrm{C}_{78} \mathrm{H}_{122} \mathrm{O}_{42}\right)$ were similar to those of $\mathbf{1}$. However, the molecular formula of 2 contained an additional $\mathrm{C}_{2} \mathrm{H}_{2} \mathrm{O}$, and signals arising from an acetyl group $\left[\delta_{\mathrm{H}} 2.14(\mathrm{~s}) ; \delta_{\mathrm{C}} 170.9\right.$ and 21.0$]$ were observed in the ${ }^{1} \mathrm{H}$ - and ${ }^{13} \mathrm{C}-\mathrm{NMR}$ spectra of 2 . These data suggest that $\mathbf{2}$ is a monoacetylated derivative of $\mathbf{1}$. The HMBC spectrum of 2 exhibited long-range correlations from $\mathrm{H}_{2}-6^{\prime \prime \prime \prime \prime \prime}$ of Glc $\left(\delta_{\mathrm{H}} 4.91\right.$ and 4.65$)$ to the carbonyl carbon of the acetyl moiety $\left(\delta_{C}\right.$ 170.9). Comparing the ${ }^{13} \mathrm{C}-\mathrm{NMR}$ spectrum of 2 with that of $\mathbf{1}$, the signal attributable to C- 6 "'"' by $1.8 \mathrm{ppm}$. The above data indicate that the acetyl group is attached to C- 6 "'"'" of Glc. Therefore, 2 was identified as $3 \beta-[(O-\beta$-D-galactopyranosyl- $(1 \rightarrow 2)-O-[\beta-D-x y l o p y r a n o s y l-(1 \rightarrow 3)]-\beta-$ D-glucuronopyranosyl)oxy]-16 $\alpha$-hydroxy-23-oxo-olean-12-en-28-oic acid $O-(6-O$-acetyl- $\beta$-Dglucopyranosyl)-(1 $\rightarrow 3)-O-[\beta$-D-xylopyranosyl- $(1 \rightarrow 4)]-O-\alpha$-L-rhamnopyranosyl- $(1 \rightarrow 2)-O-[\beta$ D-quinovopyranosyl- $(1 \rightarrow 4)]-\beta$-D-fucopyranosyl ester.

Compound 3 was obtained as an amorphous solid, and its molecular formula was determined to be $\mathrm{C}_{76} \mathrm{H}_{120} \mathrm{O}_{41}$ based on the accurate sodium adduct ion at $\mathrm{m} / z 1711.7191$ $[\mathrm{M}+\mathrm{Na}]^{+}$(calculated for $\mathrm{C}_{76} \mathrm{H}_{120} \mathrm{NaO}_{41}$ : 1711.7203) in the HR-ESI-TOF-MS as well as the ${ }^{13} \mathrm{C}$-NMR spectral data. The ${ }^{1} \mathrm{H}$ - and ${ }^{13} \mathrm{C}-\mathrm{NMR}$ spectral features of 3 resembled those of $\mathbf{1 0}$, except for those of the sugar moiety attached to C-28 of the aglycone. The ${ }^{1} \mathrm{H}-{ }^{1} \mathrm{H}$ COSY, 1D-TOCSY, HSQC, and HSQC-TOCSY spectra indicated that the sugar moiety attached to $\mathrm{C}-28$ of the aglycone consisted of a 2,4-disubstituted $\beta$-D-fucopyranosyl unit [Fuc: $\delta_{\mathrm{H}}$ $5.94\left(\mathrm{~d}, J=8.4 \mathrm{~Hz}, \mathrm{H}-1^{\prime \prime \prime \prime}\right.$ of Fuc); $\delta_{\mathrm{C}} 94.6,74.4,76.8,84.0,71.6$, and 17.1 (C-1"'"-C-6"'” 
of Fuc)], a 4-substituted $\alpha$-L-rhamnopyranosyl unit [Rha: $\delta_{\mathrm{H}} 6.34$ (br s, H-1"'"' of Rha; $\delta_{\mathrm{C}} 101.2,71.8,72.4,83.5,68.3$, and $18.6\left(\mathrm{C}-1^{\prime \prime \prime \prime \prime}-\mathrm{C}-6^{\prime \prime \prime \prime \prime}\right.$ of Rha); $\left.\left.{ }^{1} J_{\mathrm{H}-1, \mathrm{C}-1}=169 \mathrm{~Hz}\right)\right]$, a 3substituted $\beta$-D-xylopyranosyl unit [Xyl (II): $\delta_{\mathrm{H}} 5.16$ (d, $J=7.2 \mathrm{~Hz}, \mathrm{H}-1^{\prime \prime \prime \prime \prime \prime \prime ~ o f ~ X y l ~(I I) ; ~} \delta_{\mathrm{C}}$ $106.2,74.8,88.2,69.3$, and 66.7 (C-1"'"'"-C-5"'"'" of Xyl (II))], a terminal $\beta$-D-glucopyranosyl unit [Glc: $\delta_{\mathrm{H}} 5.18\left(\mathrm{~d}, J=7.8 \mathrm{~Hz}, \mathrm{H}-1^{\prime \prime \prime \prime \prime \prime \prime \prime ~ o f ~ G l c) ; ~} \delta_{\mathrm{C}} 105.5,75.4,78.3,71.5,78.6\right.$, and 62.5 (C-1"''"'-C-6"'"'"' of Glc)], and a terminal $\beta$-D-quinovopyranosyl unit [Qui: $\delta_{\mathrm{H}} 4.97(\mathrm{~d}$,

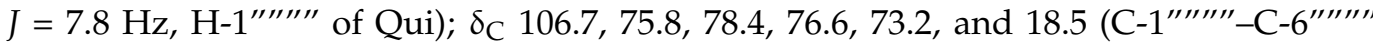
of Qui)]. HMBC correlations were observed between H-1"'"'"' of Glc and C-3"'"'" of Xyl (II), H-1"'"'" of Xyl (II) and C-4"'"' of Rha, H-1"'"' of Rha and C-2"'" of Fuc, H-1"'"'"' of Qui and C-4"'" of Fuc, and between H-1"'" of Fuc and C-28 $\left(\delta_{C} 176.0\right)$ of the aglycone. Therefore, 3 was identified as $3 \beta-[(O-\beta$-D-galactopyranosyl- $(1 \rightarrow 2)-O-[\beta-D-x y l o p y r a n o s y]-$ $(1 \rightarrow 3)]$ - $\beta$-D-glucuronopyranosyl)oxy]-16 $\alpha$-hydroxy-23-oxo-olean-12-en-28-oic acid $O-\beta$-Dglucopyranosyl-( $(1 \rightarrow 3)-O-\beta$-D-xylopyranosyl- $(1 \rightarrow 4)-O-\alpha$-L-rhamnopyranosyl- $(1 \rightarrow 2)-O$ - $[\beta$ D-quinovopyranosyl- $(1 \rightarrow 4)]-\beta$-D-fucopyranosyl ester.

Comparison of the ${ }^{1} \mathrm{H}$ - and ${ }^{13} \mathrm{C}-\mathrm{NMR}$ spectra of $4\left(\mathrm{C}_{80} \mathrm{H}_{124} \mathrm{O}_{43}\right)$ with those of 3 exhibited considerable structural similarity. However, the molecular formula of 4 contained an additional $\mathrm{C}_{4} \mathrm{H}_{4} \mathrm{O}_{2}$, and signals arising from two acetyl groups were observed in the ${ }^{1} \mathrm{H}$ - and ${ }^{13} \mathrm{C}-\mathrm{NMR}$ spectra of $4\left[\delta_{\mathrm{H}} 2.04(\mathrm{~s}) ; \delta_{\mathrm{C}} 170.1\right.$ and 20.7; and $\delta_{\mathrm{H}} 1.96(\mathrm{~s}) ; \delta_{\mathrm{C}} 170.4$ and 20.6]. These data suggest that 4 is a diacetylated analog of 3 . In the HMBC spectrum of 4 , long-range correlations were observed from $\mathrm{H}-3^{\prime \prime \prime \prime \prime \prime \prime \prime ~ o f ~ Q u i ~}\left(\delta_{\mathrm{H}} 5.60\right)$ to an acetyl carbonyl carbon $\left(\delta_{\mathrm{C}} 170.4\right)$, and from H-4"'"'"'" of Qui $\left(\delta_{\mathrm{H}} 5.05\right)$ to another acetyl carbonyl carbon $\left(\delta_{\mathrm{C}} 170.1\right)$. Accordingly, 4 was determined to be $3 \beta-[(O-\beta$-D-galactopyranosyl- $(1 \rightarrow 2)-O-[\beta-D-x y l o p y r a n o s y l-(1 \rightarrow 3)]-\beta$-Dglucuronopyranosyl)oxy]-16 $\alpha$-hydroxy-23-oxo-olean-12-en-28-oic acid $O-\beta$-D-glucopyranosyl$(1 \rightarrow 3)$-O- $\beta$-D-xylopyranosyl-( $(\rightarrow 4)$-O- $\alpha$-L-rhamnopyranosyl-( $1 \rightarrow 2)$-O-[3,4-di-O-acetyl- $\beta$-D-q uinovopyranosyl-( $1 \rightarrow 4)]-\beta$-D-fucopyranosyl ester.

The ${ }^{1} \mathrm{H}$ - and ${ }^{13} \mathrm{C}$-NMR spectral data of $\mathbf{5}\left(\mathrm{C}_{53} \mathrm{H}_{84} \mathrm{O}_{25}\right)$ suggested that $\mathbf{5}$ was analogous to 15 , including the sugar moieties attached to $\mathrm{C}-3$ and $\mathrm{C}-28$ of the aglycone. The molecular formula of 5 contained an additional oxygen atom in comparison to that of $\mathbf{1 5}\left(\mathrm{C}_{53} \mathrm{H}_{84} \mathrm{O}_{24}\right)$. Comparing the ${ }^{13} \mathrm{C}-\mathrm{NMR}$ spectrum of 5 with that of $\mathbf{1 5}$, the methylene carbon signal $\left(\delta_{\mathrm{C}}\right.$ 21.1) attributed to $\mathrm{C}-16$ in $\mathbf{1 5}$ was displaced by the oxygenated methine carbon signal $\left(\delta_{\mathrm{C}} 74.1\right)$ in 5. Furthermore, $\mathrm{H}-16\left(\delta_{\mathrm{H}} 5.23\right)$ showed a spin-coupling correlation with $\mathrm{H}_{2}-15\left(\delta_{\mathrm{H}} 2.48\right.$ and 1.69) in the ${ }^{1} \mathrm{H}^{-1} \mathrm{H}$ COSY spectrum of 5 , and long-range correlations were observed between $\mathrm{H}-18\left(\delta_{\mathrm{H}} 3.47\right) / \mathrm{H}_{2}-22\left(\delta_{\mathrm{H}} 2.26\right.$ and 2.01) and $\mathrm{C}-16$ in the HMBC spectrum. The above spectral data indicate the presence of a hydroxy group at $\mathrm{C}-16$ in 5. The configuration of the $\mathrm{C}-16$ hydroxy group was determined to be $\alpha$ based on the nuclear Overhauser effect (NOE) correlations between $\mathrm{H}-16$ and $\mathrm{H}-15 \alpha / \mathrm{H}-15 \beta / \mathrm{H}-22 \alpha$ in the nuclear Overhauser and exchange spectroscopy (NOESY) spectrum of 5 (Figure 2). Thus, 5 was deduced to be $16 \alpha$-hydroxy-3 $\beta$-[( $\beta$-D-xylopyranosyl)oxy]olean-12-en-23,28-dioic acid 28 -O- $\beta$-D-glucopyranosyl-( $1 \rightarrow 2)$-O- $\beta$-D-glucopyranosyl-( $(\rightarrow 6)-\beta$-D-glucopyranosyl ester.

Compound $6\left(\mathrm{C}_{65} \mathrm{H}_{102} \mathrm{O}_{33}\right)$ was shown to be essentially analogous to 16 , including the sugar moieties attached to $\mathrm{C}-3$ and $\mathrm{C}-28$ of the aglycone, based on the ${ }^{1} \mathrm{H}-$ and ${ }^{13} \mathrm{C}-$ NMR spectral data. However, the molecular formula of 6 contained an additional $\mathrm{C}_{6} \mathrm{H}_{8} \mathrm{O}_{4}$ compared to that of $\mathbf{1 6}\left(\mathrm{C}_{59} \mathrm{H}_{94} \mathrm{O}_{29}\right)$, and the ${ }^{13} \mathrm{C}$-NMR spectra of $\mathbf{6}$ indicated the presence of a six-atom substituent, which was composed of an ester carbonyl carbon $\left(\delta_{\mathrm{C}} 171.7, \mathrm{C}-1^{\prime \prime \prime \prime \prime \prime}\right)$,

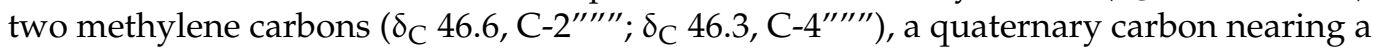
hydroxy group $\left(\delta_{C} 70.0, C-3^{\prime \prime \prime \prime \prime \prime}\right)$, a carbonyl carbon of a carboxy group $\left(\delta_{C} 174.7, C-5^{\prime \prime \prime \prime \prime \prime}\right)$, and a methyl carbon $\left(\delta_{C} 28.2, C-6^{\prime \prime \prime \prime \prime \prime)}\right)$. The signals in the ${ }^{1} \mathrm{H}-\mathrm{NMR}$ spectrum that could be assigned to this substituent involved two isolated spin systems consisting of two methyl groups $\left[\delta_{\mathrm{H}} 3.18\left(1 \mathrm{H}, \mathrm{d}, J=15.0 \mathrm{~Hz}, \mathrm{H}-4^{\prime \prime \prime \prime \prime \prime a) ~ a n d ~} 3.15\left(1 \mathrm{H}, \mathrm{d}, J=15.0 \mathrm{~Hz}, \mathrm{H}-44^{\prime \prime \prime \prime \prime}\right) ; \delta_{\mathrm{H}}\right.\right.$ : $3.16\left(1 \mathrm{H}, \mathrm{d}, J=14.3 \mathrm{~Hz}, \mathrm{H}-2^{\prime \prime \prime \prime \prime \prime} \mathrm{a}\right)$ and $\left.3.11\left(1 \mathrm{H}, \mathrm{d}, J=14.3 \mathrm{~Hz}, \mathrm{H}-2^{\prime \prime \prime \prime \prime \prime} \mathrm{b}\right)\right]$ and a deshielded methyl group $\left[\delta_{\mathrm{H}} 1.75\left(3 \mathrm{H}, \mathrm{s}, \mathrm{Me}-6^{\prime \prime \prime \prime \prime \prime)}\right)\right.$. These spectroscopic data indicated that the substituent was 3-hydroxy-3-methylglutaryl (HMG). In the HMBC spectrum of 6, a longrange correlation was observed between $\mathrm{H}_{2}-6^{\prime \prime \prime \prime}\left(\delta_{\mathrm{H}} 4.92\right.$ and 4.68) of Glc (III) and C-1"'"' of the HMG moiety. Accordingly, 6 was identified as $3 \beta-[(\beta-D-x y l o p y r a n o s y l) o x y]-o l e a n-12-$ 
en-23,28-dioic acid 28-O- $\beta$-D-glucopyranosyl-( $1 \rightarrow 2)$-O-(6-O-3-hydroxy-3-methylglutaryl- $\beta$ D-glucopyranosyl)-( $1 \rightarrow 6)$-O-[ $\beta$-D-glucopyranosyl-( $1 \rightarrow 3)]-\beta$-D-glucopyranosyl ester.

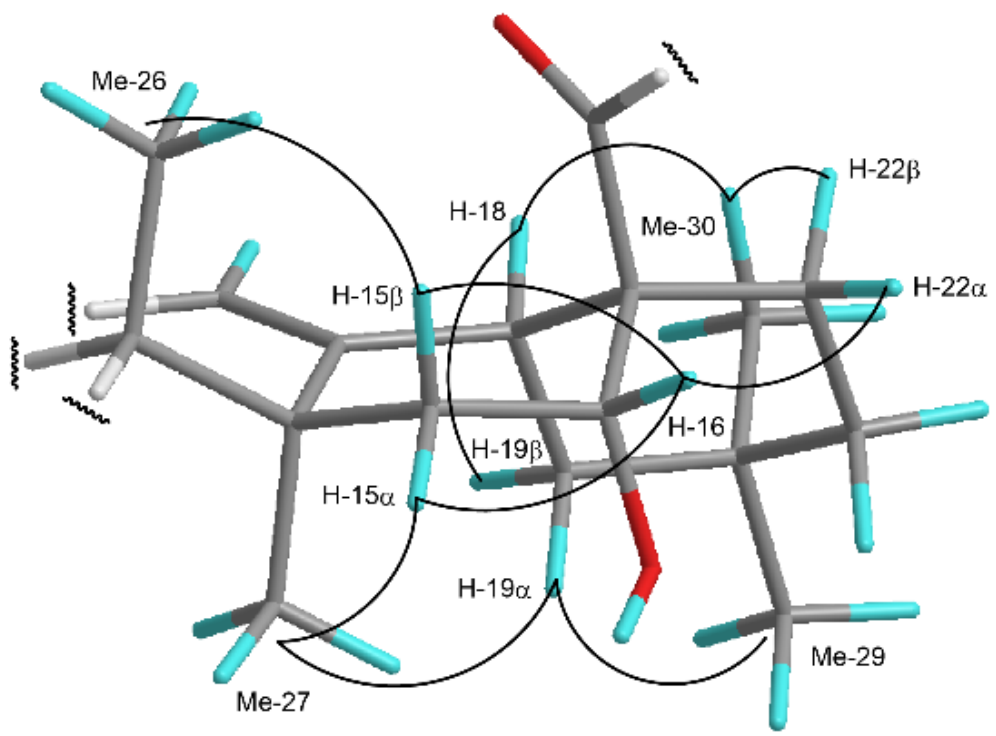

Figure 2. Important NOE correlations observed in the NOESY spectrum of 5 . The C-16 $\alpha$ hydroxy configuration was confirmed based on the NOE correlations between $\mathrm{H}-16$ and $\mathrm{H}-15 \alpha / \mathrm{H}-15 \beta / \mathrm{H}-22 \alpha$.

Comparison of the ${ }^{1} \mathrm{H}$ - and ${ }^{13} \mathrm{C}-\mathrm{NMR}$ spectra of $\mathbf{7}\left(\mathrm{C}_{65} \mathrm{H}_{102} \mathrm{O}_{34}\right)$ with those of $\mathbf{6}$ suggested that 7 was closely related to 6 , and that they both shared the same sugar moieties at C-3 and C-28 of the aglycone. The molecular formula of 7 contained an additional oxygen atom compared to that of 6 , and the methylene carbon signal $\left(\delta_{C} 23.1\right)$ assigned to $C-16$ in 6 was displaced by the oxygenated methine carbon signal $\left(\delta_{C} 74.0\right)$ in 7 . Furthermore, $\mathrm{H}-16\left(\delta_{\mathrm{H}} 5.20\right)$ exhibited a spin-coupling correlation with $\mathrm{H}_{2}-15\left(\delta_{\mathrm{H}} 2.38\right.$ and 1.65) in the ${ }^{1} \mathrm{H}-{ }^{1} \mathrm{H}$ COSY spectrum of 7 , and long-range correlations were observed between $\mathrm{H}-18\left(\delta_{\mathrm{H}}\right.$ 3.46) $/ \mathrm{H}_{2}-22\left(\delta_{\mathrm{H}} 2.33\right.$ and 2.08) and C-16 in the HMBC spectrum of 7. Thus, the presence of a hydroxy group at C-16 of the aglycone, as in 5, was evident. In the NOESY spectrum of 7 , NOE correlations were observed between $\mathrm{H}-16$ and $\mathrm{H}-15 \alpha / \mathrm{H}-15 \beta / \mathrm{H}-22 \alpha$. Therefore, the configuration at the $\mathrm{C}-16$ hydroxy group was ascertained to be $\alpha$. Compound 7 was elucidated as $16 \alpha$-hydroxy-3 $\beta$-[( $\beta$-D-xylopyranosyl)oxy]olean-12-en-23,28-dioic acid 28$O$ - $\beta$ - D-glucopyranosyl-( $1 \rightarrow 2)$-O-(6-O-3-hydroxy-3-methylglutaryl- $\beta$-D-glucopyranosyl)$(1 \rightarrow 6)$-O-[ $\beta$-D-glucopyranosyl-( $\rightarrow 3)]-\beta$-D-glucopyranosyl ester. The configurations of the asymmetric centers of the HMG moiety of 6 and 7 could not be determined presently, owing to insufficient compound quantities.

\subsection{Cytotoxic Activities of $\mathbf{1} \mathbf{- 1 7}$}

The cytotoxic activities of 1-17 against HL-60 cells, A549 cells, and SBC-3 cells were evaluated using the modified 3-(4,5-dimethylthiazol-2-yl)-2,5-diphenyl-2-tetrazolium bromide (MTT) assay (Table 1). As shown in Figure 3, 1-5, 9, and 10 exerted cytotoxic effects in a dose-dependent manner. The cytotoxicities of $\mathbf{1}, \mathbf{4}$, and $\mathbf{1 0}$ toward HL-60 cells and SBC-3 cells were almost as potent as that of cisplatin, which was used as the positive control.

\subsection{Apotosis-Inducing Activity of $\mathbf{1}$}

Compound 1 exhibited potent cytotoxic activity against SBC- 3 cells and was obtained in a good yield. Thus, the apoptosis-inducing activity of $\mathbf{1}$ in SBC-3 cells was evaluated. Prior to assessing the apoptosis-inducing activity, SBC-3 cells were exposed to either 1 or cisplatin for $24 \mathrm{~h}$ to obtain $\mathrm{IC}_{50}$ values. The $\mathrm{IC}_{50}$ values of $\mathbf{1}$ and cisplatin were calculated to be 7.3 and $8.6 \mu \mathrm{M}$, respectively, based on the dose-response curves (Figure 4). Thus, the apoptosis-inducing activity of $\mathbf{1}$ was evaluated at $10 \mu \mathrm{M}$. 
Table 1. Cytotoxic activities of 1-17 against HL-60 cells, A549 cells, and SBC-3 cells ${ }^{(1)}$.

\begin{tabular}{|c|c|c|c|c|c|c|c|c|c|}
\hline \multirow{3}{*}{$\begin{array}{c}\text { Compounds } \\
1\end{array}$} & \multirow{2}{*}{\multicolumn{3}{|c|}{$\begin{array}{c}\text { HL-60 Cells } \\
\mathrm{IC}_{50}(\mu \mathrm{M})\end{array}$}} & \multirow{2}{*}{\multicolumn{3}{|c|}{$\begin{array}{c}\text { A549 Cells } \\
\mathrm{IC}_{50}(\mu \mathrm{M})\end{array}$}} & \multirow{2}{*}{\multicolumn{3}{|c|}{$\begin{array}{c}\text { SBC-3 Cells } \\
\mathrm{IC}_{50}(\mu \mathrm{M})\end{array}$}} \\
\hline & & & & & & & & & \\
\hline & 1.8 & \pm & 0.038 & 8.4 & \pm & 0.055 & 0.84 & \pm & 0.012 \\
\hline 2 & 4.0 & \pm & 0.039 & 21 & \pm & 0.17 & 1.5 & \pm & 0.052 \\
\hline 3 & 5.4 & \pm & 0.084 & 10 & \pm & 0.10 & 1.7 & \pm & 0.015 \\
\hline 4 & 0.57 & \pm & 0.0030 & 3.3 & \pm & 0.21 & 0.59 & \pm & 0.0015 \\
\hline 5 & 21 & \pm & 0.26 & & $>50$ & & 10 & \pm & 0.15 \\
\hline 6 & & $>50$ & & & $>50$ & & & $>50$ & \\
\hline 7 & & $>50$ & & & $>50$ & & & $>50$ & \\
\hline 8 & & $>50$ & & & $>50$ & & & $>50$ & \\
\hline 9 & 11 & \pm & 0.27 & 16 & \pm & 0.020 & 1.7 & \pm & 0.023 \\
\hline 10 & 1.1 & \pm & 0.010 & 7.7 & \pm & 0.062 & 0.61 & \pm & 0.0072 \\
\hline 11 & & $>50$ & & & $>50$ & & & $>50$ & \\
\hline 12 & & $>50$ & & & $>50$ & & & $>50$ & \\
\hline 13 & & $>50$ & & & $>50$ & & & $>50$ & \\
\hline 14 & & $>50$ & & & $>50$ & & & $>50$ & \\
\hline 15 & & $>50$ & & & $>50$ & & & $>50$ & \\
\hline 16 & & $>50$ & & & $>50$ & & & $>50$ & \\
\hline 17 & & $>50$ & & & $>50$ & & & $>50$ & \\
\hline Cisplatin & 2.0 & \pm & 0.019 & 2.5 & \pm & 0.079 & 0.23 & \pm & 0.0049 \\
\hline
\end{tabular}

(1) Data are represented as the mean value \pm S.E.M. of the three experiments performed in triplicate.

\subsubsection{Apoptosis Induced by 1}

After SBC-3 cells were treated with 1 for 24 h, the cells were stained with Annexin V and propidium iodide (PI), and the apoptotic cell ratio was analyzed using flow cytometry. The percentage of early (Q4 area) and late (Q2 area) apoptotic cell populations increased significantly to $10 \pm 0.32 \%$ and $33 \pm 1.5 \%$ for 1 compared to $2.0 \pm 0.058 \%$ and $2.2 \pm 0.12 \%$, respectively, for the vehicle control (Figure 5).

\subsubsection{Cell Cycle Arrest at the $G_{2} / M$ Phase by 1}

To determine the cell cycle distribution of SBC-3 cells treated with $\mathbf{1}$, flow cytometry analysis was performed using PI staining. After $12 \mathrm{~h}$ of treatment with 1 , the cell population in the $\mathrm{G}_{2} / \mathrm{M}$ phase (P5 area) increased to $35 \pm 0.45 \%$ from $23 \pm 0.48 \%$, which was the value obtained after treatment with the vehicle control (Figure 6A,B). Furthermore, the sub-G phase (P2 area) population of SBC-3 cells treated with 1 for $24 \mathrm{~h}$ was $28 \pm 0.23 \%$, while that after treatment with the vehicle control was $4.1 \pm 0.15 \%$ (Figure 6C,D). These data indicated that 1 arrested SBC-3 cell proliferation in the $\mathrm{G}_{2} / \mathrm{M}$ phase and induced apoptotic cell death.

\subsubsection{Caspase Activation and PARP Cleavage by 1}

Caspases, which are cysteine proteases that cleave after aspartic acid residues in a substrate, play an important role in apoptosis and are subclassified into initiator caspases (caspase- 8 and -9) and executioner caspases (caspase-3, -6, -7) [25]. During apoptosis, PARP cleavage is a useful hallmark of this type of cell death [26]. To confirm the contribution of caspases to the induction of apoptosis by 1, Western blotting analysis was performed. After SBC-3 cells were treated with 1 for $24 \mathrm{~h}$, proteins were extracted and subjected to Western blotting analysis. As a result, the activation of caspase- $8,-9$, and -3 , and PARP cleavage were observed (Figure 7). 
A
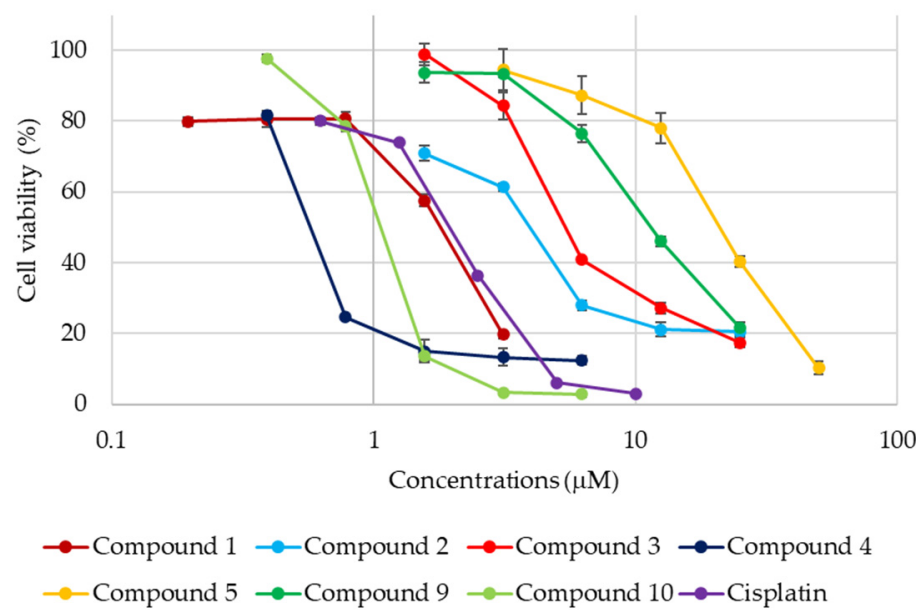

B

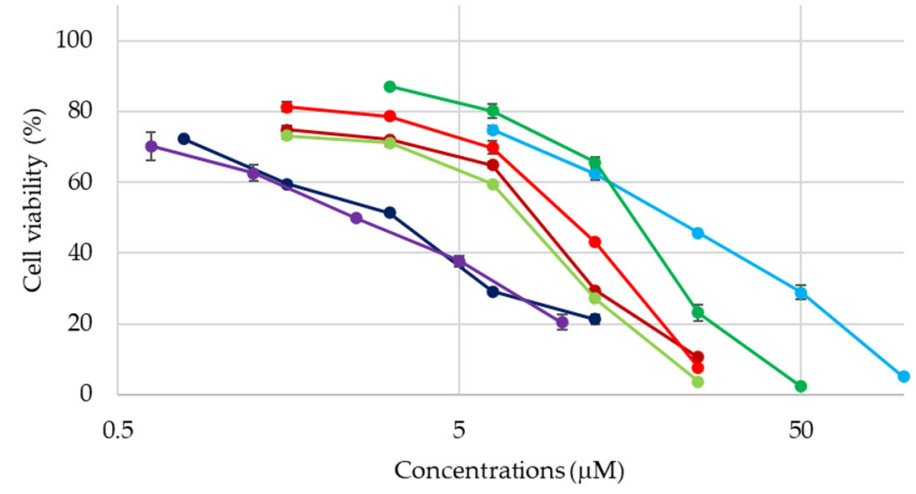

$\rightarrow$ Compound $1 \rightarrow-$ Compound $2 \rightarrow$ Compound $3 \rightarrow$ Compound 4

$\rightarrow$ Compound $9 \rightarrow$ Compound $10 \rightarrow$ Cisplatin

C

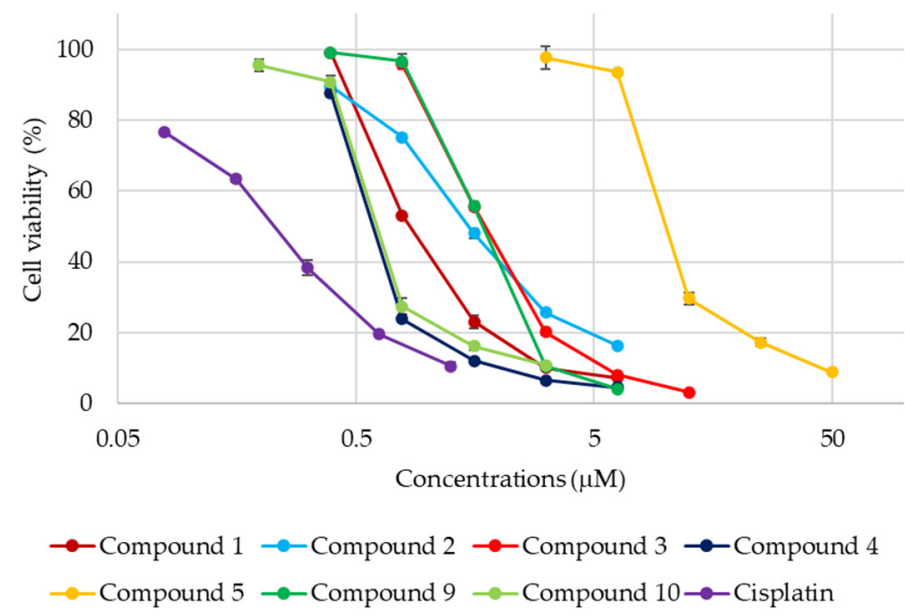

Figure 3. Dose-response curves of 1-5, 9, 10, and cisplatin. HL-60 and SBC-3 cells were treated with either 1-5, 9, 10, or cisplatin for $72 \mathrm{~h}(\mathrm{~A}, \mathrm{C})$, and A549 cells were treated with either 1-4, 9, 10, or cisplatin for $72 \mathrm{~h}(\mathbf{B})$. The cell viability was evaluated by the modified MTT assay. 


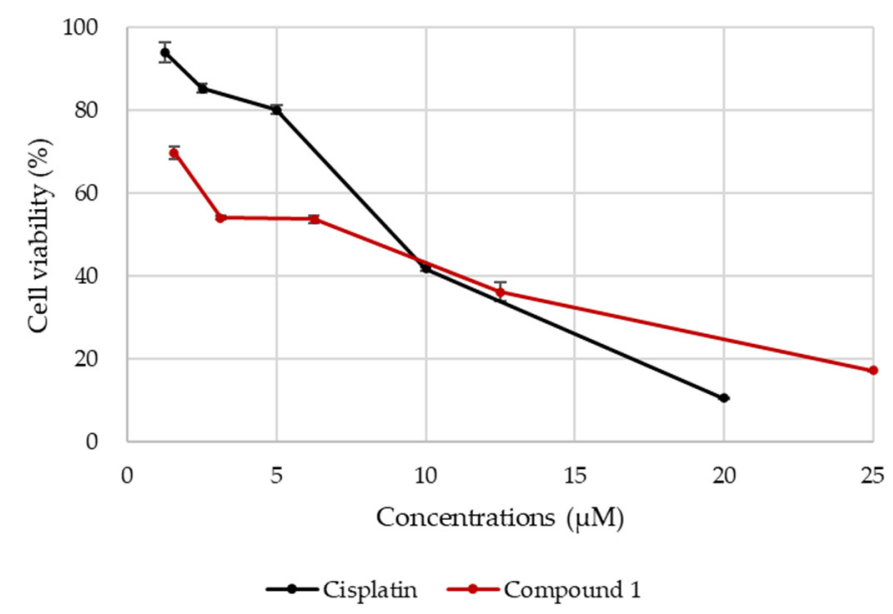

Figure 4. Dose-response curves of $\mathbf{1}$ and cisplatin. SBC-3 cells were treated with either $\mathbf{1}$ or cisplatin for $24 \mathrm{~h}$, and the cell viability was evaluated by the modified MTT assay.

A

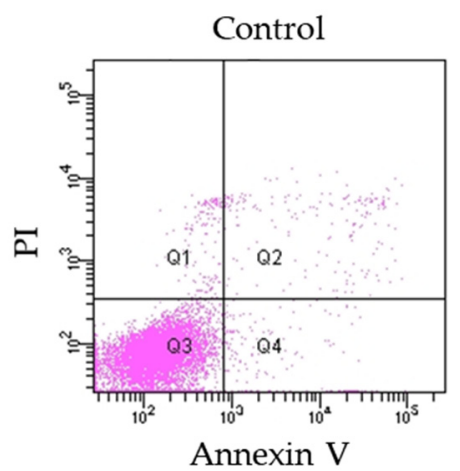

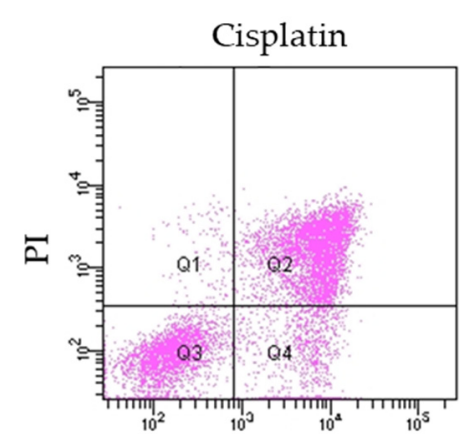

Annexin V

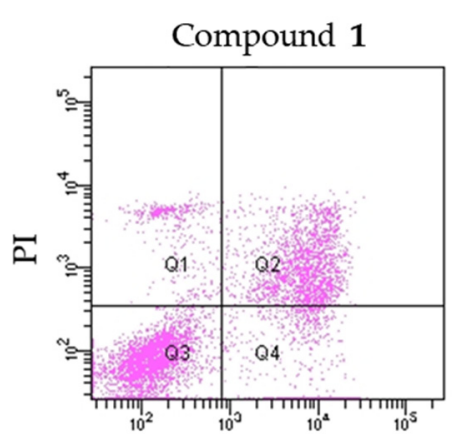

Annexin V

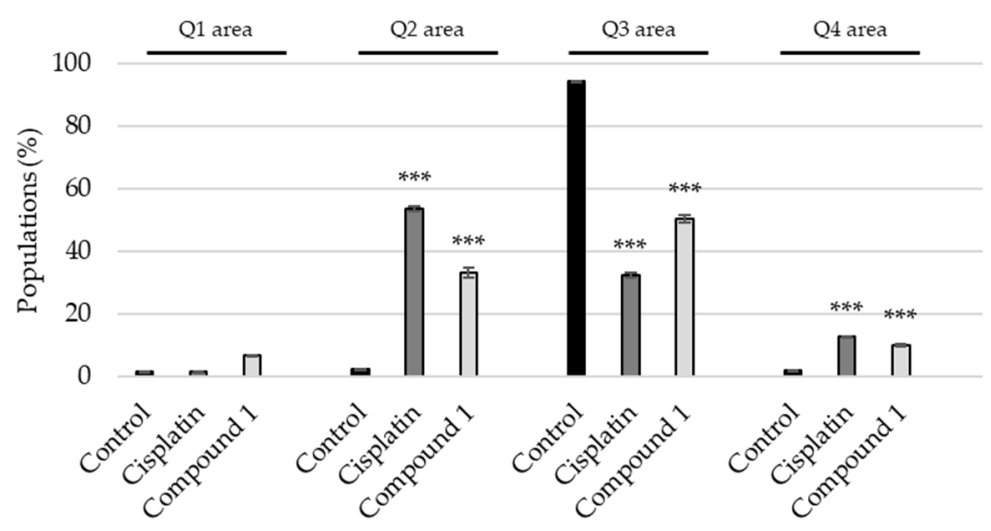

Figure 5. Detection of apoptosis in SBC-3 cells treated with cisplatin or 1. (A) SBC-3 cells treated with either $10 \mu \mathrm{M}$ of cisplatin or $10 \mu \mathrm{M}$ of 1 . After $24 \mathrm{~h}$ treatment, SBC-3 cells were stained with Annexin $\mathrm{V}$ and propidium iodide (PI), and then analyzed using a flow cytometer. (B) The bar graph for the percentage of populations of dead cells ( $\mathrm{Q} 1$ area), late apoptotic cells ( $\mathrm{Q} 2$ area), live cells (Q3 area), and early apoptotic cells (Q4 area) ${ }^{* * *} p<0.001$ vs. vehicle control). 
A

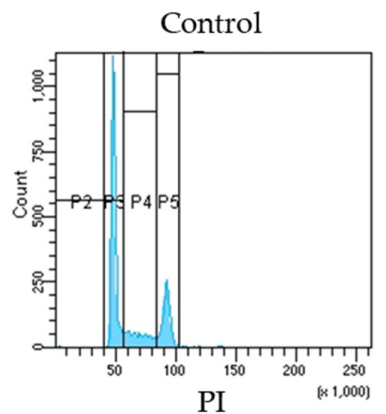

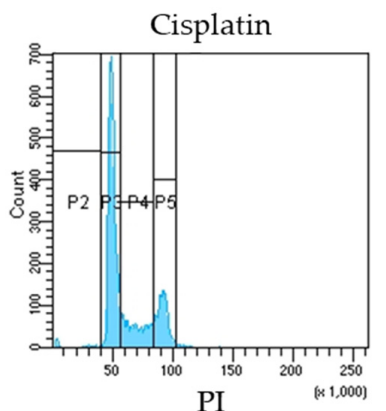

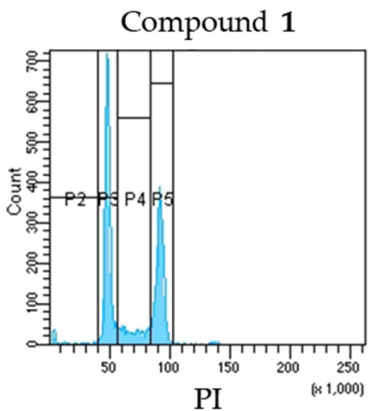

B

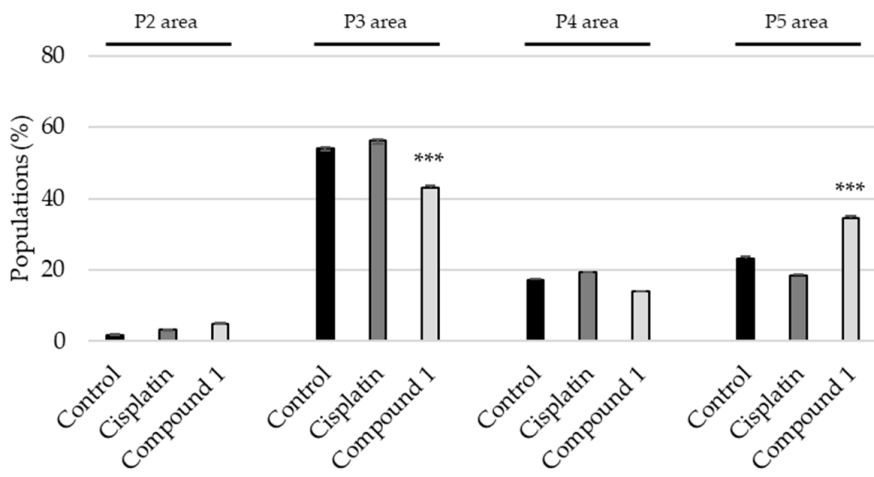

C
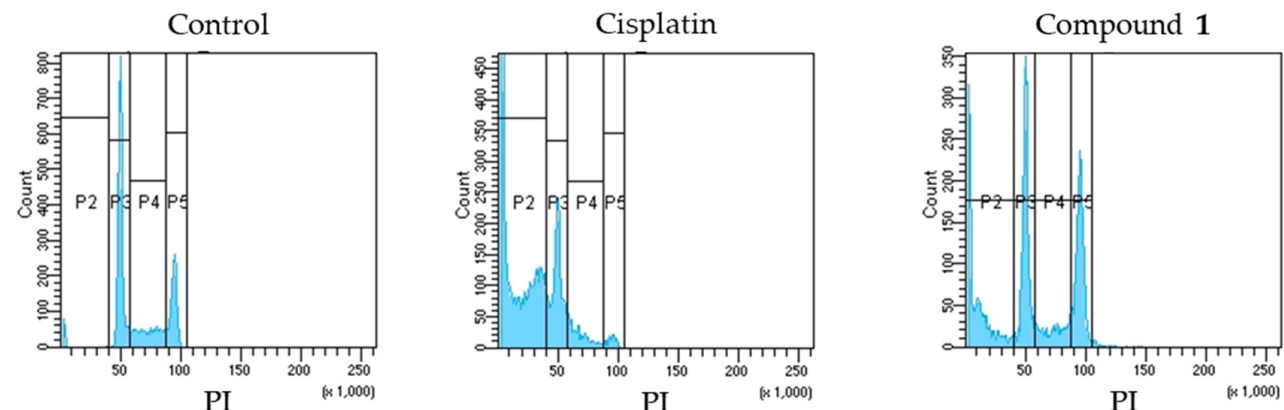

D

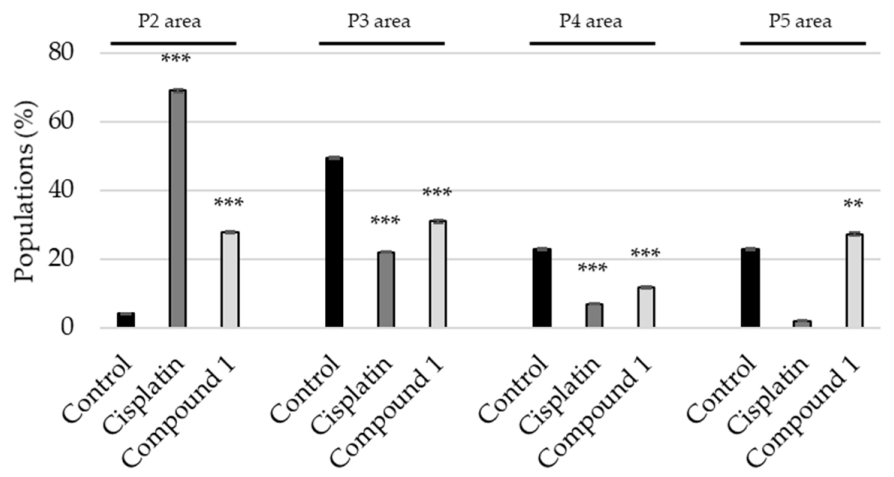

Figure 6. Cell cycle progression of SBC-3 cells treated with cisplatin or 1. (A,C) SBC-3 cells were incubated with either $10 \mu \mathrm{M}$ of cisplatin or $10 \mu \mathrm{M}$ of $\mathbf{1}$ for $12 \mathrm{~h}$ and $24 \mathrm{~h}$, and the cell cycle distribution was analyzed using a flow cytometer. (B,D) The cell percentages in the sub-G 1 (P2 area), $G_{0} / G_{1}$ (P3 area), $\mathrm{S}$ (P4 area), and $\mathrm{G}_{2} / \mathrm{M}$ (P5 area) phase are shown as the mean \pm S.E.M. of three experiments for $12 \mathrm{~h}$ and $24 \mathrm{~h}$ treatments $\left({ }^{* *} p<0.001,{ }^{* *} p<0.01\right.$ vs. vehicle control). 


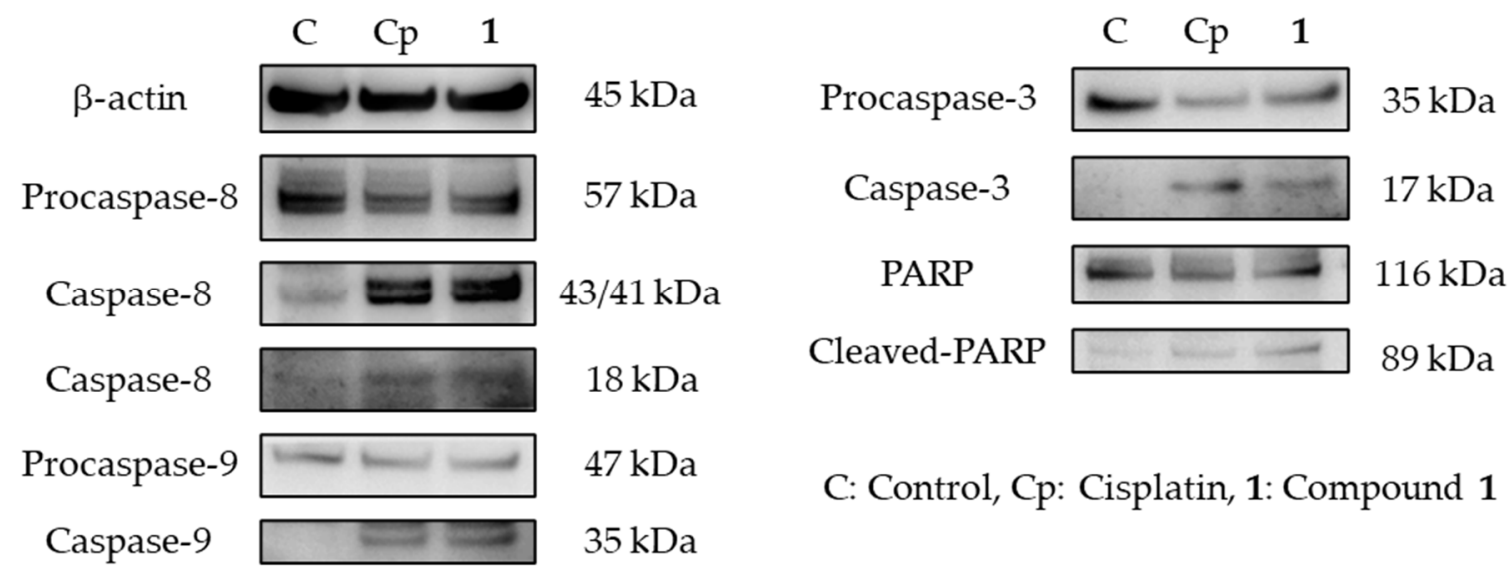

Figure 7. Expression of $\beta$-actin, caspase-8, $-9,-3$, and PARP in SBC-3 cells treated with cisplatin or 1. SBC-3 cells were incubated with either $10 \mu \mathrm{M}$ of cisplatin or $10 \mu \mathrm{M}$ of 1 for $24 \mathrm{~h}$, and the expression of $\beta$-actin, caspase- $8,-9,-3$, and cleaved-PARP was detected using Western blotting analysis.

\subsubsection{Mitochondrial Dysfunction Induced by 1}

There are two major apoptosis-inducing pathways: intrinsic and extrinsic. The intrinsic pathway is also known as the mitochondrial pathway and participates in the activation of caspase-9 [27]. Because the activation of caspase-9 in SBC-3 cells treated with 1 was confirmed, the mitochondrial membrane potential was evaluated employing the JC- 1 assay. When cells are stained with JC- 1 dye, at low mitochondrial membrane potentials, the concentration of JC-1 is low and it exists predominantly as a monomer, exhibiting green fluorescence with emission; at high mitochondrial membrane potentials, the dye accumulates in the mitochondria and the dye aggregates yield a red to red-colored emission. SBC-3 cells were treated with $\mathbf{1}$ for $24 \mathrm{~h}$, and then analyzed using a flow cytometer. As shown in Figure 8, the population of the mitochondrial membrane potential depolarized cells significantly increased compared to that observed with the vehicle control. Additionally, the expression of $\mathrm{Bcl}-2$ and Bax was evaluated employing Western blot analysis. Bcl-2 and Bax belong to the Bcl-2 family, which regulates the intrinsic apoptotic pathway. Bcl-2 is an anti-apoptotic protein, whereas Bax acts as a pro-apoptotic effector [28]. In SBC-3 cells treated with 1, the expression level of Blc-2 was remarkably diminished, and the ratio of $\mathrm{Bcl}-2 / \mathrm{Bax}$ was lower than that of the vehicle control (Figure 9). These data suggest that 1 causes mitochondrial dysfunction in SBC-3 cells.

\subsubsection{ROS Generation by $\mathbf{1}$}

Reactive oxygen species (ROS) exhibit beneficial or harmful effects on cells and tissues. ROS have been reported to be associated with intrinsic and extrinsic apoptotic pathways [29,30]. SBC-3 cells were incubated with either $2.5 \mathrm{mM}$ of $\mathrm{N}$-acetylcysteine (NAC; negative control), $100 \mu \mathrm{M}$ of tert-butyl hydroperoxide (TBHP; positive control), or $\mathbf{1}$ for $24 \mathrm{~h}$, and then analyzed using a flow cytometer. As depicted in Figure 10, the cell fluorescence intensities of the control- and NAC-treated groups were weak, while the peaks of the cell populations of the TBHP- or 1-treated groups moved to the right side. Based on these results it can be concluded that ROS generation occurred in SBC-3 cells treated with 1 .

\subsection{Mitophagy Occurrence}

Mitophagy is defined as mitochondria-selective autophagy and plays a role in the elimination of defective mitochondria [31]. Several reports have suggested that depolarization of the mitochondrial membrane potential and ROS production are involved in mitophagy [32-34]. As 1 induced depolarization of the mitochondrial membrane potential and ROS generation, we investigated whether mitophagy occurred in SBC-3 cells. SBC-3 cells were treated with 1 or $7.5 \mu \mathrm{M}$ of carbonyl cyanide $m$-chlorophenylhydrazone (CCCP; positive control) for $24 \mathrm{~h}$, and then stained with Mtphagy Dye and Lyso Dye. Mtphagy Dye 
is a fluorescent dye that binds mitochondria and emits red fluorescence, the intensity of which increases under acidic conditions when the mitochondria are fused with lysosomes. Lyso Dye stains lysosomes and emits green fluorescence. SBC-3 cells incubated with 1 emitted intense red fluorescence and exhibited co-localization with lysosomes, while those treated with the control did not (Figure 11). These findings suggest that mitophagy had occurred in SBC-3 cells.

A

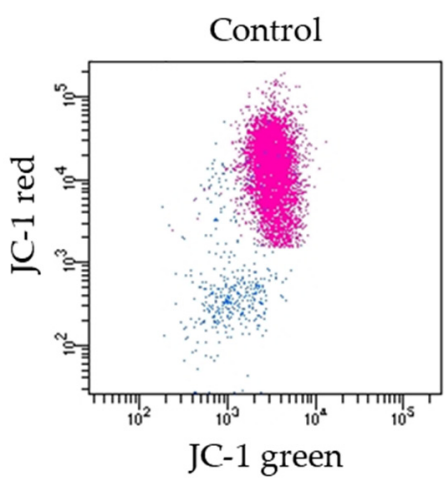

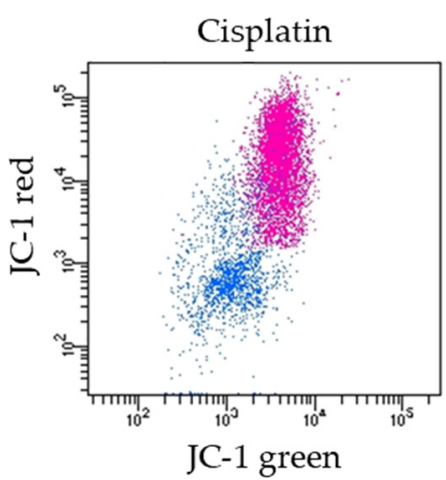

Compound 1

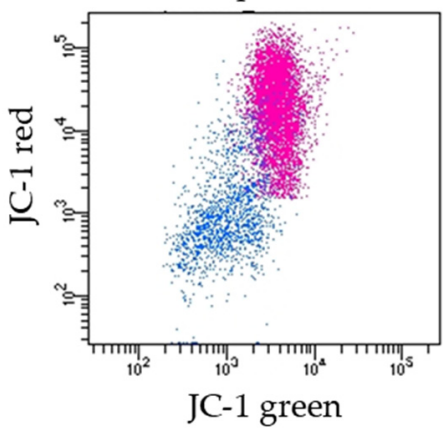

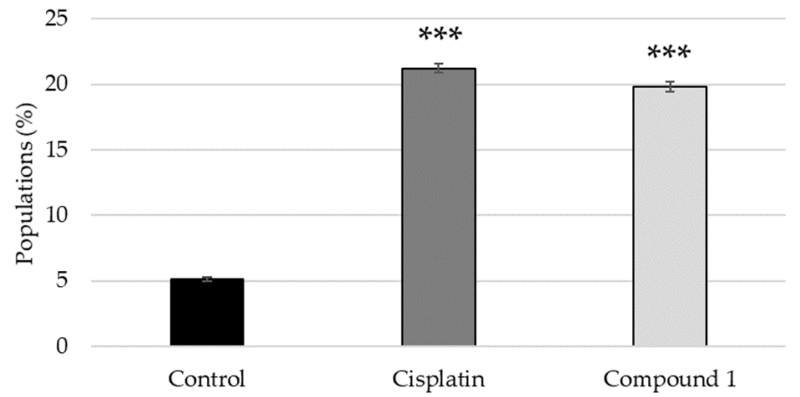

Figure 8. Mitochondrial membrane potential detection in SBC-3 cells treated with cisplatin or 1. (A) SBC-3 cells were treated with either $10 \mu \mathrm{M}$ of cisplatin or $10 \mu \mathrm{M}$ of $\mathbf{1}$ for $24 \mathrm{~h}$, and then stained with JC-1 followed by flow cytometry analysis. (B) The percentage of mitochondria membrane potential depolarized cells (blue dots) is exhibited as the mean \pm S.E.M. of three experiments ${ }^{* * *} p<0.001$ vs. vehicle control).

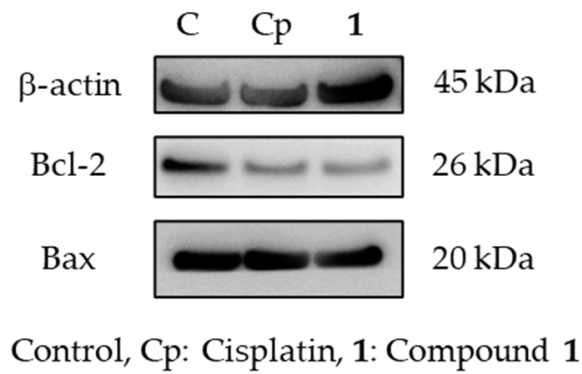

Figure 9. Expression of $\beta$-actin, Bcl-2, and Bax in SBC-3 cells treated with cisplatin or 1 . SBC-3 cells were treated with either $10 \mu \mathrm{M}$ of cisplatin or $10 \mu \mathrm{M}$ of $\mathbf{1}$ for $24 \mathrm{~h}$, and the expression of $\beta$-actin, Bcl-2, and Bax was evaluated using Western blotting analysis. 
A

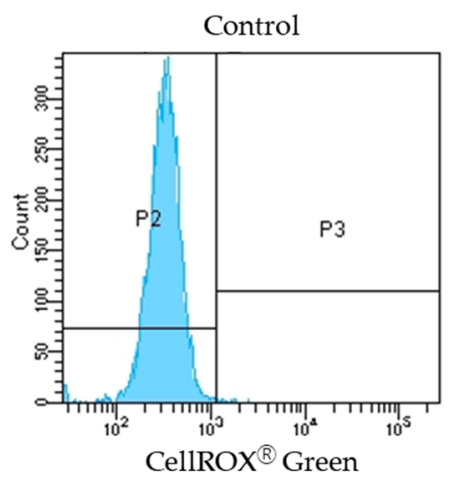

NAC

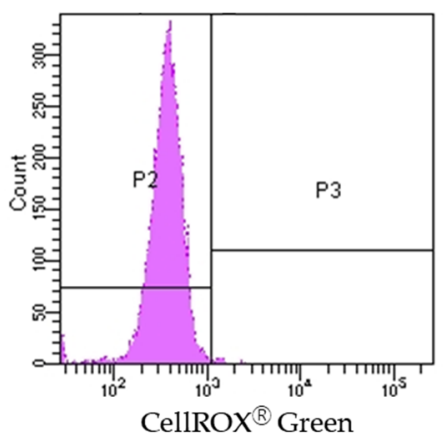

TBHP

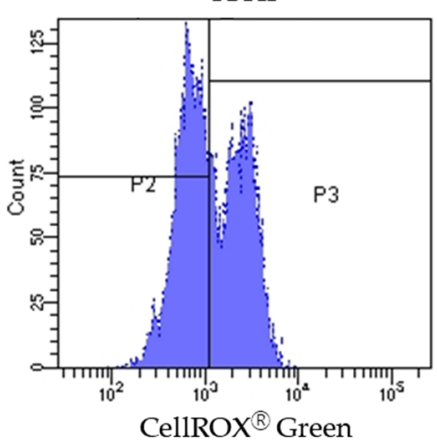

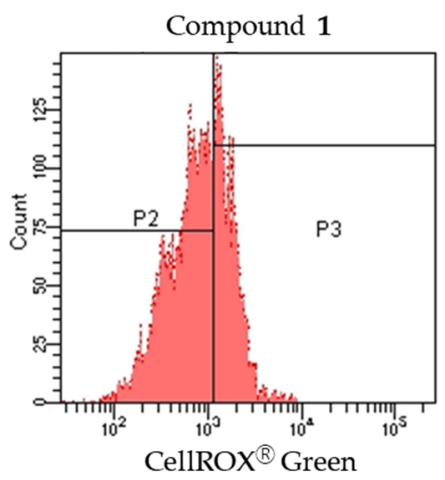

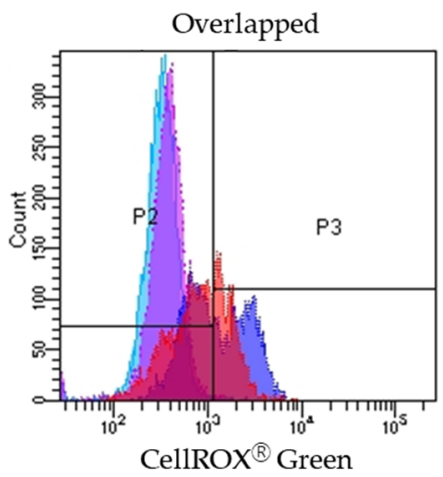

B

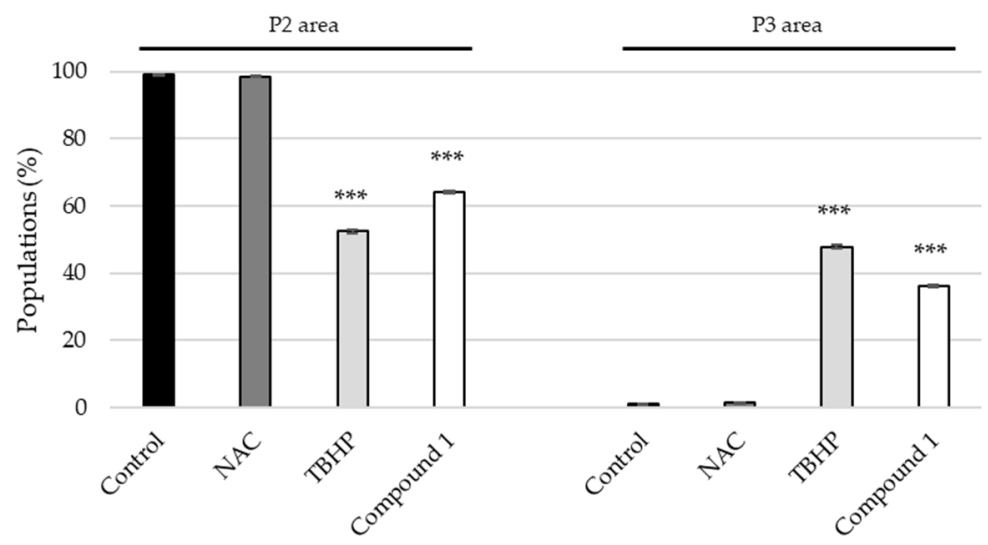

Figure 10. ROS production in SBC-3 cells treated with either $N$-acetylcysteine (NAC), tert-butyl hydroperoxide (TBHP) or 1. (A) SBC-3 cells were incubated with either $2.5 \mathrm{mM}$ of NAC, $100 \mu \mathrm{M}$ of TBHP, or $10 \mu \mathrm{M}$ of $\mathbf{1}$ for $24 \mathrm{~h}$. ROS levels were analyzed using a flow cytometer. (B) The percentage of cells in the P2 area and P3 area are shown as the mean \pm S.E.M. of three experiments ${ }^{* * *} p<0.001$ vs. vehicle control). 


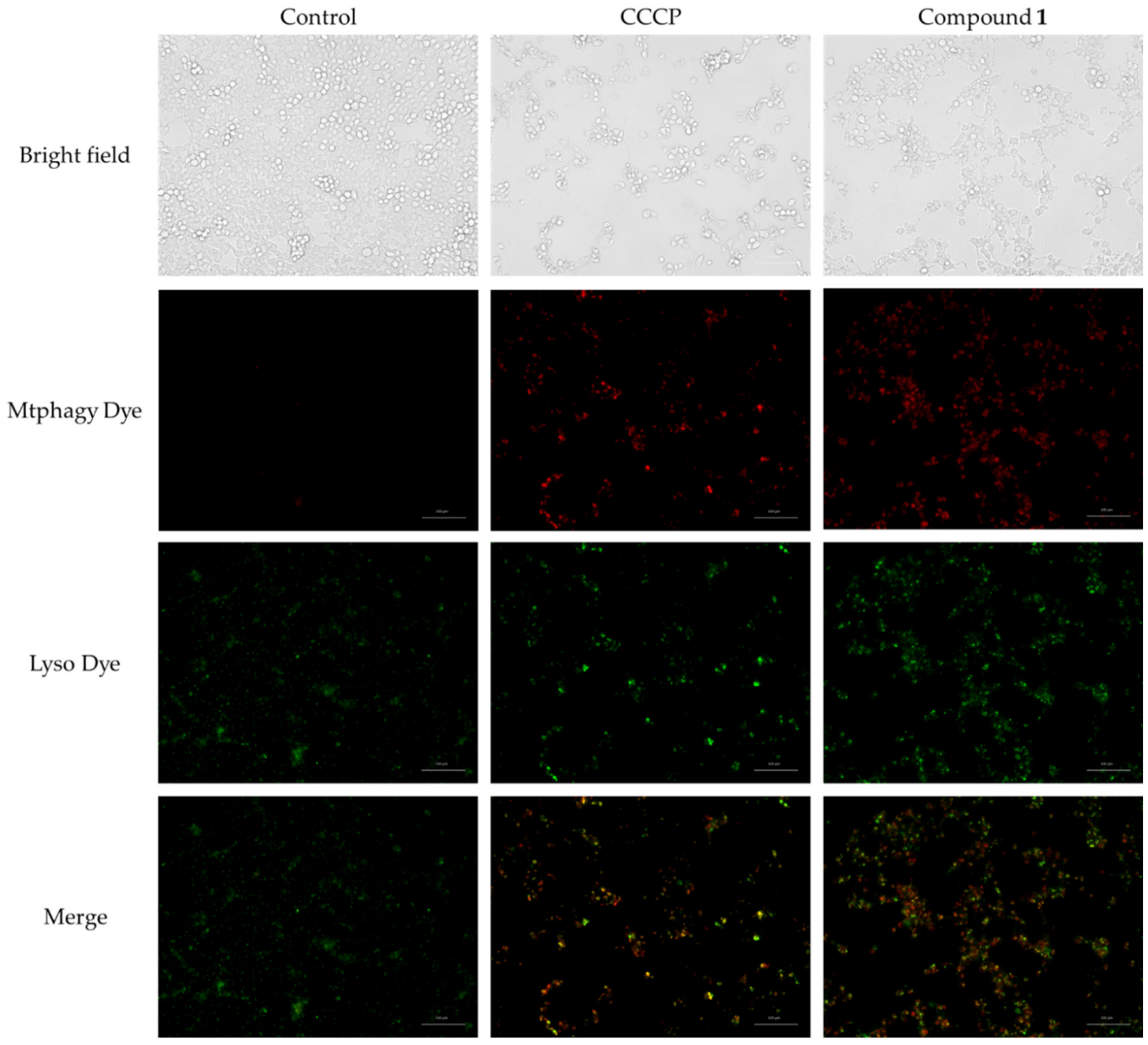

Figure 11. Mitophagy occurrence in SBC-3 cells treated with carbonyl cyanide $m$-chlorophenylhydrazone (CCCP) or $\mathbf{1}$. SBC-3 cells were treated with either $7.5 \mu \mathrm{M}$ of CCCP or $10 \mu \mathrm{M}$ of $\mathbf{1}$ for $24 \mathrm{~h}$ and observed by a fluorescence microscopy. The scale bars indicate $100 \mu \mathrm{m}$.

\section{Materials and Methods}

\subsection{General Experimental Procedures}

Optical rotations were measured using a P-1030 automatic digital polarimeter (JASCO, Tokyo, Japan). IR spectral data were obtained on a Fourier-transform infrared (FT-IR) 620 spectrometer (JASCO). NMR spectral data were collected using a Bruker AVIIIHD600 (600 MHz for ${ }^{1} \mathrm{H}-\mathrm{NMR}$; $150 \mathrm{MHz}$ for ${ }^{13} \mathrm{C}-\mathrm{NMR}$ ) spectrometer (Karlsruhe, Germany) and JNM-ECZ600R/M1 (600 MHz for ${ }^{1} \mathrm{H}-\mathrm{NMR}$; $150 \mathrm{MHz}$ for $\left.{ }^{13} \mathrm{C}-\mathrm{NMR}\right)$ spectrometer (JEOL, Tokyo, Japan) at $300 \mathrm{~K}$. Chemical shifts are recorded as $\delta$ values and referenced to tetramethylsilane (TMS) as the internal standard. HR-ESI-TOF-MS data were collected by a Waters Micromass LCT mass spectrometer (Milford, MA, USA). Diaion HP-20 porous polymer polystyrene resin (Mitsubishi-Chemical, Tokyo, Japan), silica gel Chromatorex BW-300 (Fuji-Silysia Chemical, Aichi, Japan), and ODS silica gel COSMOSIL $75 \mathrm{C}_{18}$-OPN (Nacalai-Tesque, Kyoto, Japan) were adopted for CC. Thin layer chromatography (TLC) analysis was conducted using precoated silica gel $60 \mathrm{~F}_{254}$ or $\mathrm{RP} 18 \mathrm{~F}_{254} \mathrm{~S}$ plates $(0.25 \mathrm{~mm}$ thick; Merck, Darmstadt, Germany). The sample spots were visualized by spraying the TLC plates with $\mathrm{H}_{2} \mathrm{SO}_{4} / \mathrm{H}_{2} \mathrm{O}(1: 9)$, and then heating. The preparative HPLC system consisted of an LC-20AD pump (Shimadzu, Kyoto, Japan), a RID-10A detector (Shimadzu), 
a Rheodyne injection port (Thermo Fisher Scientific, Waltham, MA, USA), and a TSKgel ODS-100Z column (10 mm i.d. $\times 250 \mathrm{~mm}, 5 \mu \mathrm{m}$; Tosoh, Tokyo, Japan). The purities of the isolated compounds were confirmed by NMR spectra and TLC. The following materials and reagents were recruited for the cell culture and cytotoxic assays: SH-1300 Lab microplate reader (CORONA ELECTRIC, Ibaraki, Japan); 96-well flat-bottomed and 6-well flat-bottomed plates (Iwaki Glass, Chiba, Japan), Countess II FL automated cell counter (Thermo Fisher Scientific); $\mathrm{MCO}-170 \mathrm{AIC}-\mathrm{PJ} \mathrm{CO}_{2}$ incubator (PHC, Tokyo, Japan); $0.25 \%$ trypsin-ethylenediaminetetraacetic acid (EDTA) solution, fetal-bovine serum (FBS), RPMI-1640 medium, minimum-essential medium (MEM), cisplatin, and MTT (Sigma, St. Louis, MO, USA); penicillin G sodium salt and streptomycin sulfate, and TrypLE Select $(1 \times)$ (Gibco, Gland Island, NY, USA); paraformaldehyde and phosphate-buffered saline (PBS) (FUJIFILM Wako Pure Chemical, Osaka, Japan); HL-60 cells (JCRB0085), A549 cells (JCRB0076), and SBC-3 cells (JCRB0818) (Human Science Research Resource Bank, Osaka, Japan).

\subsection{Plant Material}

S. officinalis seeds were purchased from Richters Herbs (Goodwood, Ontario, Canada) in 2010. A voucher specimen was maintained at the herbarium of the Tokyo University of Pharmacy and Life Sciences (KS-2010-003).

\subsection{Extraction and Isolation}

The seeds of $S$. officinalis $(1.0 \mathrm{~kg})$ were extracted with $\mathrm{MeOH}\left(2 \mathrm{~L} \times 2\right.$ times, $\left.60{ }^{\circ} \mathrm{C}\right)$, and then the solvent was removed under reduced pressure using an evaporator. The $\mathrm{MeOH}$ extract (50 g) was loaded on Diaion HP-20 column and successively eluted with $\mathrm{MeOH} / \mathrm{H}_{2} \mathrm{O}(1: 4 ; 2 \mathrm{~L}), \mathrm{EtOH}(3 \mathrm{~L})$, and EtOAc (3 L). The EtOH eluted fraction (10 g) was subjected to silica gel $\mathrm{CC}$ eluted with a stepwise gradient mixture of $\mathrm{CHCl}_{3} / \mathrm{MeOH}(9: 1$; $4: 1 ; 2: 1$ ) to obtain four fractions [Fractions (Frs.) A-D]. Fr. A was divided by ODS silica gel CC eluted with $\mathrm{MeCN} / \mathrm{H}_{2} \mathrm{O}(2: 5)$ and $\mathrm{MeOH} / \mathrm{H}_{2} \mathrm{O}(3: 2)$, and preparative ODS HPLC using $\mathrm{MeCN} / \mathrm{H}_{2} \mathrm{O}(7: 13)$ to afford $13(3.0 \mathrm{mg})$ and $15(26 \mathrm{mg})$. Fr. B was subjected to silica gel CC eluted with $\mathrm{CHCl}_{3} / \mathrm{MeOH} / \mathrm{H}_{2} \mathrm{O}$ (7:4:1), ODS silica gel CC eluted with $\mathrm{MeOH} / \mathrm{H}_{2} \mathrm{O}$ (7:3) and $\mathrm{MeCN} / \mathrm{H}_{2} \mathrm{O}(7: 13 ; 1: 2 ; 2: 5)$, and preparative ODS HPLC using $\mathrm{MeOH} / \mathrm{H}_{2} \mathrm{O}(7: 3$; 3:7) and $\mathrm{MeCN} / \mathrm{H}_{2} \mathrm{O}(3: 7)$ to yield $5(7.1 \mathrm{mg}), 6(2.5 \mathrm{mg})$, and 12 (4.1 mg). Fr. C was separated by silica gel CC eluted with $\mathrm{CHCl}_{3} / \mathrm{MeOH} / \mathrm{H}_{2} \mathrm{O}$ (7:4:1), ODS silica gel CC eluted with $\mathrm{MeOH} / \mathrm{H}_{2} \mathrm{O}(13: 7)$ and $\mathrm{MeCN} / \mathrm{H}_{2} \mathrm{O}(2: 5 ; 3: 7)$, and preparative ODS HPLC using $\mathrm{MeOH} / \mathrm{H}_{2} \mathrm{O}(13: 7)$ and $\mathrm{MeCN} / \mathrm{H}_{2} \mathrm{O}(3: 7)$ to furnish 7 (3.2 mg), 10 (84 mg), 11 (4.9 mg), and $14(2.0 \mathrm{mg})$. Fr. D was chromatographed on silica gel eluted with $\mathrm{CHCl}_{3} / \mathrm{MeOH} / \mathrm{H}_{2} \mathrm{O}$ (7:4:1), and ODS silica gel eluted with $\mathrm{MeOH} / \mathrm{H}_{2} \mathrm{O}(3: 2 ; 13: 7)$ and $\mathrm{MeCN} / \mathrm{H}_{2} \mathrm{O}(7: 13 ; 3: 7$; 1:3) to obtain 1 (184 mg), 2 (38 mg), 3 (4.6 mg), 4 (15 mg), 8 (19 mg), 9 (49 mg), 16 (23 mg), and 17 (55 mg).

\subsection{Structural Determination}

Compound 1: Amorphous solid; $[\alpha]_{\mathrm{D}}^{25}-4.9(c=0.10, \mathrm{MeOH}) ; \mathrm{IR}$ (film) $v_{\max }: 3398$ $(\mathrm{OH}), 2929(\mathrm{CH}), 1730(\mathrm{C}=\mathrm{O}) \mathrm{cm}^{-1}$; HR-ESI-TOF-MS m/z: $1711.7161\left[\mathrm{M}+\mathrm{Na}^{+}\right.$(calculated $^{-}$ for $\mathrm{C}_{76} \mathrm{H}_{120} \mathrm{NaO}_{41}$ : 1711.7203). ${ }^{1} \mathrm{H}-\mathrm{NMR}$ spectral data for the aglycone moiety $(600 \mathrm{MHz}$, $\left.\mathrm{C}_{5} \mathrm{D}_{5} \mathrm{~N}\right): \delta_{\mathrm{H}} 9.91(1 \mathrm{H}, \mathrm{s}, \mathrm{H}-23), 5.50(1 \mathrm{H}, \mathrm{m}, \mathrm{H}-12), 5.11(1 \mathrm{H}$, br s, H-16), $4.06(1 \mathrm{H}, \mathrm{m}, \mathrm{H}-3)$, $1.73(3 \mathrm{H}, \mathrm{s}, \mathrm{Me}-27), 1.46$ (3H, s, Me-24), 1.10 (3H, s, Me-26), 0.93 (3H, s, Me-30), 0.92 (3H, s, Me-29), 0.84 (3H, s, Me-25). ${ }^{1} \mathrm{H}-\mathrm{NMR}$ spectral data for the sugar moiety, see Table 2. ${ }^{13}$ C-NMR spectral data, see Table 3. NMR spectral data, see Supplementary Materials. 
Table 2. ${ }^{1} \mathrm{H}-\mathrm{NMR}$ spectral data for the sugar and acyl moieties of 1-7.

\begin{tabular}{|c|c|c|c|c|c|c|c|c|c|}
\hline \multicolumn{5}{|c|}{1} & \multicolumn{5}{|c|}{2} \\
\hline \multicolumn{2}{|c|}{ Positions } & \multicolumn{2}{|r|}{$\delta_{\mathrm{H}}$} & \multirow[t]{2}{*}{$J(\mathrm{~Hz})$} & \multicolumn{2}{|c|}{ Positions } & \multicolumn{2}{|r|}{$\delta_{\mathrm{H}}$} & \multirow[t]{2}{*}{$J(\mathrm{~Hz})$} \\
\hline GlcUA & & & & & GlcUA & & & & \\
\hline $1^{\prime}$ & & 4.89 & $\mathrm{~d}$ & 7.8 & $1^{\prime}$ & & 4.89 & $\mathrm{~d}$ & 7.8 \\
\hline $2^{\prime}$ & & 4.34 & $\mathrm{dd}$ & $8.3,7.8$ & $2^{\prime}$ & & 4.33 & $\mathrm{dd}$ & $8.4,7.8$ \\
\hline $3^{\prime}$ & & 4.24 & $\mathrm{dd}$ & $9.1,8.3$ & $3^{\prime}$ & & 4.22 & $\mathrm{dd}$ & $9.0,8.4$ \\
\hline $4^{\prime}$ & & 4.45 & $\mathrm{dd}$ & $9.4,9.1$ & $4^{\prime}$ & & 4.44 & $\mathrm{dd}$ & $9.6,9.0$ \\
\hline $5^{\prime}$ & & 4.50 & $\mathrm{~d}$ & 9.4 & $5^{\prime}$ & & 4.49 & $\mathrm{~d}$ & 9.6 \\
\hline Gal & & & & & Gal & & & & \\
\hline $1^{\prime \prime}$ & & 5.54 & $\mathrm{~d}$ & 7.7 & $1^{\prime \prime}$ & & 5.53 & * & \\
\hline $2^{\prime \prime}$ & & 4.46 & $\mathrm{dd}$ & $8.8,7.7$ & $2^{\prime \prime}$ & & 4.44 & $\mathrm{dd}$ & $9.0,7.8$ \\
\hline $3^{\prime \prime}$ & & 4.16 & $\mathrm{dd}$ & $8.8,3.2$ & $3^{\prime \prime}$ & & 4.15 & $\mathrm{dd}$ & $9.0,3.6$ \\
\hline $4^{\prime \prime}$ & & 4.58 & br d & 3.2 & $4^{\prime \prime}$ & & 4.56 & br d & 3.6 \\
\hline $5^{\prime \prime}$ & & 4.02 & $\mathrm{~m}$ & & $5^{\prime \prime}$ & & 4.00 & $\mathrm{~m}$ & \\
\hline \multirow{2}{*}{$6^{\prime \prime}$} & $\mathrm{a}$ & 4.51 & $\mathrm{~m}$ & & $6^{\prime \prime}$ & $\mathrm{a}$ & 4.50 & $\mathrm{~m}$ & \\
\hline & $\mathrm{b}$ & 4.42 & $\mathrm{~m}$ & & & $\mathrm{~b}$ & 4.41 & $\mathrm{dd}$ & $10.8,6.0$ \\
\hline Xyl (I) & & & & & Xyl (I) & & & & \\
\hline $1^{\prime \prime \prime}$ & & 5.31 & $\mathrm{~d}$ & 7.7 & $1^{\prime \prime \prime}$ & & 5.30 & $\mathrm{~d}$ & 7.8 \\
\hline $2^{\prime \prime \prime}$ & & 3.96 & $\mathrm{dd}$ & $9.1,7.7$ & $2^{\prime \prime \prime}$ & & 3.96 & $\mathrm{dd}$ & $8.4,7.8$ \\
\hline $3^{\prime \prime \prime}$ & & 4.13 & $\mathrm{~m}$ & & $3^{\prime \prime \prime}$ & & 4.11 & $\mathrm{dd}$ & $8.4,7.8$ \\
\hline $4^{\prime \prime \prime}$ & & 4.12 & $\mathrm{~m}$ & & $4^{\prime \prime \prime}$ & & 4.12 & $\mathrm{~m}$ & \\
\hline \multirow[t]{2}{*}{$5^{\prime \prime \prime}$} & $\mathrm{a}$ & 4.23 & $\mathrm{dd}$ & $11.7,5.3$ & $5^{\prime \prime \prime}$ & $\mathrm{a}$ & 4.24 & $\mathrm{~m}$ & \\
\hline & $\mathrm{b}$ & 3.65 & $\mathrm{~m}$ & & & $\mathrm{~b}$ & 3.65 & $\mathrm{dd}$ & $11.2,9.3$ \\
\hline Fuc & & & & & Fuc & & & & \\
\hline $1^{\prime \prime \prime \prime}$ & & 5.88 & $\mathrm{~d}$ & 8.2 & $1^{\prime \prime \prime \prime}$ & & 5.89 & d & 8.4 \\
\hline $2^{\prime \prime \prime \prime}$ & & 4.45 & $\mathrm{dd}$ & $9.1,8.2$ & $2^{\prime \prime \prime \prime}$ & & 4.61 & $\mathrm{dd}$ & $9.0,8.4$ \\
\hline $3 " \prime \prime$ & & 4.14 & $\mathrm{dd}$ & $9.1,3.1$ & $3^{\prime \prime \prime \prime}$ & & 4.21 & $\mathrm{~m}$ & \\
\hline $4^{\prime \prime \prime \prime}$ & & 3.98 & br d & 3.1 & $4^{\prime \prime \prime \prime}$ & & 4.01 & br d & 3.0 \\
\hline $5^{\prime \prime \prime \prime}$ & & 3.91 & $\mathrm{~m}$ & & $5^{\prime \prime \prime \prime}$ & & 3.99 & $\mathrm{~m}$ & \\
\hline $6^{\prime \prime \prime \prime}$ & & 1.53 & $\mathrm{~d}$ & 5.8 & $6^{\prime \prime \prime \prime}$ & & 1.59 & $\mathrm{~d}$ & 6.0 \\
\hline Rha & & & & & Rha & & & & \\
\hline $1^{\prime \prime \prime \prime \prime \prime}$ & & 6.00 & br s & & $1^{\prime \prime \prime \prime \prime \prime}$ & & 6.32 & br s & \\
\hline $2^{\prime \prime \prime \prime \prime}$ & & 5.11 & br s & & $2^{\prime \prime \prime \prime \prime}$ & & 4.97 & br s & \\
\hline $3^{\prime \prime \prime \prime \prime}$ & & 4.80 & $\mathrm{dd}$ & $9.0,2.7$ & $3^{\prime \prime \prime \prime \prime}$ & & 4.64 & br d & 9.0 \\
\hline $4^{\prime \prime \prime \prime \prime}$ & & 4.52 & $\mathrm{~m}$ & & $4^{\prime \prime \prime \prime \prime}$ & & 4.53 & $\mathrm{dd}$ & $9.0,8.7$ \\
\hline $5^{\prime \prime \prime \prime \prime}$ & & 4.50 & $\mathrm{~m}$ & & $5^{\prime \prime \prime \prime \prime}$ & & 4.55 & $\mathrm{~m}$ & \\
\hline $6^{\prime \prime \prime \prime \prime}$ & & 1.66 & $\mathrm{~d}$ & 5.8 & $6^{\prime \prime \prime \prime \prime}$ & & 1.66 & $\mathrm{~d}$ & 4.8 \\
\hline Glc & & & & & Glc & & & & \\
\hline $1^{\prime \prime \prime \prime \prime \prime}$ & & 5.39 & $\mathrm{~d}$ & 7.7 & $1^{\prime \prime \prime \prime \prime \prime}$ & & 5.24 & $\mathrm{~d}$ & 7.8 \\
\hline $2^{\prime \prime \prime \prime \prime \prime}$ & & 4.02 & $\mathrm{dd}$ & $8.8,7.7$ & $2^{\prime \prime \prime \prime \prime \prime}$ & & 3.97 & $\mathrm{dd}$ & $9.0,7.8$ \\
\hline $3^{\prime \prime \prime \prime \prime \prime}$ & & 4.13 & $\mathrm{dd}$ & $8.8,8.8$ & $3^{\prime \prime \prime \prime \prime \prime}$ & & 4.04 & $\mathrm{dd}$ & $9.0,9.0$ \\
\hline $4^{\prime \prime \prime \prime \prime \prime}$ & & 3.91 & $\mathrm{dd}$ & $8.8,8.8$ & $4^{\prime \prime \prime \prime \prime \prime}$ & & 3.91 & $\mathrm{dd}$ & $9.0,9.0$ \\
\hline $5^{\prime \prime \prime \prime \prime \prime}$ & & 4.19 & $\mathrm{~m}$ & & $5^{\prime \prime \prime \prime \prime \prime}$ & & 4.09 & $\mathrm{~m}$ & \\
\hline \multirow[t]{2}{*}{$6^{\prime \prime \prime \prime \prime \prime \prime}$} & $\mathrm{a}$ & 4.50 & $\mathrm{~m}$ & & $6^{\prime \prime \prime \prime \prime \prime}$ & $\mathrm{a}$ & 4.91 & br d & 11.4 \\
\hline & $\mathrm{b}$ & 4.28 & $\mathrm{dd}$ & $11.8,5.3$ & & $\mathrm{~b}$ & 4.65 & $\mathrm{~m}$ & \\
\hline Xyl (II) & & & & & Xyl (II) & & & & \\
\hline $1^{\prime \prime \prime \prime \prime \prime \prime ' ~}$ & & 5.50 & $\mathrm{~d}$ & 7.9 & $1^{\prime \prime \prime \prime \prime \prime \prime \prime}$ & & 5.48 & $\mathrm{~d}$ & 7.8 \\
\hline $2^{\prime \prime \prime \prime \prime \prime \prime}$ & & 3.95 & $\mathrm{dd}$ & $9.1,7.9$ & $2^{\prime \prime \prime \prime \prime \prime \prime \prime}$ & & 3.91 & $\mathrm{dd}$ & $8.7,7.8$ \\
\hline $3^{\prime \prime \prime \prime \prime \prime \prime \prime}$ & & 4.14 & $\mathrm{~m}$ & & $3^{\prime \prime \prime \prime \prime \prime \prime \prime}$ & & 4.09 & $\mathrm{dd}$ & $8.7,7.8$ \\
\hline $4^{\prime \prime \prime \prime \prime \prime \prime \prime \prime \prime \prime ~}$ & & 4.12 & $\mathrm{~m}$ & & 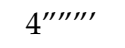 & & 4.12 & $\mathrm{~m}$ & \\
\hline \multirow[t]{2}{*}{$5^{\prime \prime \prime \prime \prime \prime \prime}$} & $\mathrm{a}$ & 4.17 & $\mathrm{~m}$ & & $5^{\prime \prime \prime \prime \prime \prime \prime}$ & $\mathrm{a}$ & 4.17 & $\mathrm{~m}$ & \\
\hline & $\mathrm{b}$ & 3.42 & $\mathrm{dd}$ & $9.1,9.1$ & & $\mathrm{~b}$ & 3.40 & $\mathrm{dd}$ & $10.2,10.2$ \\
\hline
\end{tabular}


Table 2. Cont.

\begin{tabular}{|c|c|c|c|c|c|c|c|c|c|}
\hline Qui & \multicolumn{9}{|c|}{ Qui } \\
\hline $1^{\prime \prime \prime \prime \prime \prime \prime \prime}$ & & 4.98 & $\mathrm{~d}$ & \multirow[t]{2}{*}{7.9} & \multicolumn{2}{|l|}{$1^{\prime \prime \prime \prime \prime \prime \prime \prime}$} & 4.97 & $\mathrm{~d}$ & 6.6 \\
\hline 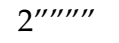 & & 3.98 & $\mathrm{~m}$ & & \multicolumn{2}{|l|}{$2 " \prime \prime \prime \prime \prime \prime$} & 4.01 & $\mathrm{dd}$ & $8.7,6.6$ \\
\hline $3^{\prime \prime \prime \prime \prime \prime \prime \prime}$ & & 3.98 & $\mathrm{~m}$ & & \multicolumn{2}{|l|}{$3 " \prime \prime \prime \prime \prime \prime$} & 4.04 & $\mathrm{dd}$ & $8.7,8.7$ \\
\hline 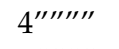 & & 4.08 & $\mathrm{dd}$ & $8.8,8.8$ & \multicolumn{2}{|l|}{ 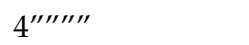 } & 3.62 & $\mathrm{~m}$ & \\
\hline "ונו"ו"ו" & & 3.63 & $\mathrm{~m}$ & & \multicolumn{2}{|l|}{$5^{\prime \prime \prime \prime \prime \prime \prime \prime \prime \prime ~}$} & 3.65 & $\mathrm{~m}$ & \\
\hline 6"ו"'ו"'ו" & & 1.54 & $\mathrm{~d}$ & 6.5 & \multicolumn{2}{|l|}{$6^{\prime \prime \prime \prime \prime \prime \prime}$} & 1.54 & $\mathrm{~d}$ & 6.0 \\
\hline & & & & & \multicolumn{2}{|l|}{ Ac } & 2.14 & $\mathrm{~s}$ & \\
\hline \multicolumn{5}{|c|}{3} & \multicolumn{5}{|c|}{4} \\
\hline \multicolumn{2}{|c|}{ Positions } & \multicolumn{2}{|c|}{$\delta_{\mathrm{H}}$} & $J(\mathrm{~Hz})$ & \multicolumn{2}{|c|}{ Positions } & \multicolumn{2}{|c|}{$\delta_{\mathrm{H}}$} & $J(\mathrm{~Hz})$ \\
\hline GlcUA & & & & & \multicolumn{2}{|l|}{ GlcUA } & & & \\
\hline $1^{\prime}$ & & 4.89 & $\mathrm{~d}$ & 7.2 & \multicolumn{2}{|l|}{$1^{\prime}$} & 4.89 & d & 7.2 \\
\hline $2^{\prime}$ & & 4.33 & $\mathrm{dd}$ & $9.0,7.2$ & \multicolumn{2}{|l|}{$2^{\prime}$} & 4.33 & $\mathrm{dd}$ & $8.4,7.2$ \\
\hline $3^{\prime}$ & & 4.27 & $\mathrm{dd}$ & $9.0,9.0$ & $3^{\prime}$ & & 4.25 & $\mathrm{dd}$ & $9.0,8.4$ \\
\hline $4^{\prime}$ & & 4.45 & $\mathrm{dd}$ & $9.6,9.0$ & $4^{\prime}$ & & 4.45 & $\mathrm{dd}$ & $9.6,9.0$ \\
\hline $5^{\prime}$ & & 4.51 & $\mathrm{~d}$ & 9.6 & $5^{\prime}$ & & 4.50 & $\mathrm{~d}$ & 9.6 \\
\hline Gal & & & & & Gal & & & & \\
\hline $1^{\prime \prime}$ & & 5.55 & $\mathrm{~d}$ & 7.8 & $1^{\prime \prime}$ & & 5.55 & * & \\
\hline $2^{\prime \prime}$ & & 4.47 & $\mathrm{dd}$ & $9.0,7.8$ & $2^{\prime \prime}$ & & 4.46 & $\mathrm{dd}$ & $9.0,7.8$ \\
\hline $3^{\prime \prime}$ & & 4.15 & $\mathrm{dd}$ & $9.0,3.6$ & $3^{\prime \prime}$ & & 4.14 & $\mathrm{dd}$ & $9.0,3.6$ \\
\hline $4^{\prime \prime}$ & & 4.57 & br d & 3.6 & $4^{\prime \prime}$ & & 4.57 & br d & 3.6 \\
\hline $5^{\prime \prime}$ & & 4.00 & $\mathrm{~m}$ & & $5^{\prime \prime}$ & & 3.99 & $\mathrm{~m}$ & \\
\hline $6^{\prime \prime}$ & $\mathrm{a}$ & 4.53 & $\mathrm{dd}$ & $10.8,6.6$ & $6^{\prime \prime}$ & $\mathrm{a}$ & 4.52 & $\mathrm{~m}$ & \\
\hline & $\mathrm{b}$ & 4.41 & $\mathrm{dd}$ & $10.8,5.4$ & & $\mathrm{~b}$ & 4.41 & $\mathrm{dd}$ & $10.2,6.0$ \\
\hline Xyl (I) & & & & & Xyl (I) & & & & \\
\hline $1^{\prime \prime \prime}$ & & 5.32 & $\mathrm{~d}$ & 7.8 & $1^{\prime \prime \prime}$ & & 5.32 & $\mathrm{~d}$ & 7.8 \\
\hline $2^{\prime \prime \prime}$ & & 3.97 & $\mathrm{dd}$ & $9.0,7.8$ & $2^{\prime \prime \prime}$ & & 3.96 & $\mathrm{dd}$ & $8.4,7.8$ \\
\hline $3^{\prime \prime \prime}$ & & 4.11 & $\mathrm{~m}$ & & $3^{\prime \prime \prime}$ & & 4.11 & $\mathrm{dd}$ & $8.4,7.8$ \\
\hline $4^{\prime \prime \prime}$ & & 4.12 & $\mathrm{~m}$ & & $4^{\prime \prime \prime}$ & & 4.12 & $\mathrm{~m}$ & \\
\hline $5^{\prime \prime \prime}$ & $\mathrm{a}$ & 4.25 & $\mathrm{dd}$ & $10.2,5.4$ & $5^{\prime \prime \prime}$ & $\mathrm{a}$ & 4.23 & $\mathrm{~m}$ & \\
\hline & $\mathrm{b}$ & 3.65 & $\mathrm{dd}$ & $10.2,9.0$ & & $\mathrm{~b}$ & 3.65 & $\mathrm{dd}$ & $9.0,8.1$ \\
\hline Fuc & & & & & Fuc & & & & \\
\hline $1^{\prime \prime \prime \prime}$ & & 5.94 & $\mathrm{~d}$ & 8.4 & $1^{\prime \prime \prime \prime}$ & & 5.92 & $\mathrm{~d}$ & 8.4 \\
\hline $2^{\prime \prime \prime \prime}$ & & 4.57 & $\mathrm{dd}$ & $9.0,8.4$ & $2^{\prime \prime \prime \prime}$ & & 4.48 & $\mathrm{dd}$ & $9.0,8.4$ \\
\hline $3^{\prime \prime \prime \prime}$ & & 4.16 & $\mathrm{dd}$ & $9.0,3.6$ & $3^{\prime \prime \prime \prime}$ & & 4.18 & $\mathrm{dd}$ & $9.0,3.0$ \\
\hline $4^{\prime \prime \prime \prime}$ & & 3.97 & br d & 3.6 & $4^{\prime \prime \prime \prime}$ & & 3.99 & br d & 3.0 \\
\hline $5^{\prime \prime \prime \prime}$ & & 3.93 & $\mathrm{dd}$ & $6.6,3.6$ & $5^{\prime \prime \prime \prime}$ & & 3.93 & $\mathrm{~m}$ & \\
\hline $6^{\prime \prime \prime \prime}$ & & 1.56 & $\mathrm{~d}$ & 6.6 & $6^{\prime \prime \prime \prime}$ & & 1.51 & $\mathrm{~d}$ & 6.0 \\
\hline Rha & & & & & Rha & & & & \\
\hline $1^{\prime \prime \prime \prime \prime \prime}$ & & 6.34 & br s & & $1^{\prime \prime \prime \prime \prime \prime}$ & & 6.20 & br s & \\
\hline $2^{\prime \prime \prime \prime \prime \prime}$ & & 4.74 & br s & & $2^{\prime \prime \prime \prime \prime}$ & & 4.70 & br s & \\
\hline $3^{\prime \prime \prime \prime \prime}$ & & 4.65 & $\mathrm{dd}$ & $9.0,3.0$ & $3^{\prime \prime \prime \prime \prime}$ & & 4.61 & br d & 9.0 \\
\hline $4^{\prime \prime \prime \prime \prime}$ & & 4.37 & $\mathrm{dd}$ & $9.6,9.0$ & $4^{\prime \prime \prime \prime \prime}$ & & 4.34 & $\mathrm{dd}$ & $9.0,8.7$ \\
\hline $5^{\prime \prime \prime \prime \prime \prime}$ & & 4.44 & $\mathrm{dd}$ & $9.6,6.0$ & $5^{\prime \prime \prime \prime \prime}$ & & 4.38 & $\mathrm{~m}$ & \\
\hline $6^{\prime \prime \prime \prime \prime}$ & & 1.62 & $\mathrm{~d}$ & 6.0 & $6^{\prime \prime \prime \prime \prime}$ & & 1.54 & d & 4.8 \\
\hline Xyl (II) & & & & & Xyl (II) & & & & \\
\hline $1^{\prime \prime \prime \prime \prime \prime}$ & & 5.16 & $\mathrm{~d}$ & 7.2 & $1^{\prime \prime \prime \prime \prime \prime \prime}$ & & 5.15 & d & 7.2 \\
\hline $2^{\prime \prime \prime \prime \prime \prime}$ & & 4.00 & $\mathrm{dd}$ & $9.0,7.2$ & $2^{\prime \prime \prime \prime \prime \prime}$ & & 3.98 & $\mathrm{dd}$ & $9.0,7.2$ \\
\hline $3^{\prime \prime \prime \prime \prime \prime}$ & & 4.01 & $\mathrm{~m}$ & & $3^{\prime \prime \prime \prime \prime \prime}$ & & 4.01 & $\mathrm{~m}$ & \\
\hline $4^{\prime \prime \prime \prime \prime \prime}$ & & 4.02 & $\mathrm{~m}$ & & $4^{\prime \prime \prime \prime \prime \prime}$ & & 4.01 & $\mathrm{~m}$ & \\
\hline $5^{\prime \prime \prime \prime \prime \prime}$ & $\mathrm{a}$ & 4.14 & $\mathrm{dd}$ & $12.0,4.8$ & $5^{\prime \prime \prime \prime \prime \prime}$ & $\mathrm{a}$ & 4.12 & $\mathrm{dd}$ & $12.0,5.4$ \\
\hline & $\mathrm{b}$ & 3.40 & $\mathrm{dd}$ & $12.0,10.2$ & & $\mathrm{~b}$ & 3.39 & $\mathrm{dd}$ & $12.0,9.6$ \\
\hline
\end{tabular}


Table 2. Cont.

\begin{tabular}{|c|c|c|c|c|c|c|c|c|c|}
\hline Glc & & & & & Glc & & & & \\
\hline $1^{\prime \prime \prime \prime \prime \prime \prime}$ & & 5.18 & $\mathrm{~d}$ & 7.8 & $1^{\prime \prime \prime \prime \prime \prime \prime}$ & & 5.18 & d & 7.8 \\
\hline 2"'"'"' & & 4.08 & $\mathrm{dd}$ & $9.0,7.8$ & 2 & & 4.08 & $\mathrm{dd}$ & $9.0,7.8$ \\
\hline $3^{\prime \prime \prime \prime \prime \prime \prime}$ & & 4.22 & $\mathrm{dd}$ & $9.0,9.0$ & $3^{\prime \prime \prime \prime \prime \prime \prime \prime \prime \prime \prime ~}$ & & 4.21 & $\mathrm{dd}$ & $9.0,9.0$ \\
\hline $4^{\prime \prime \prime \prime \prime \prime \prime \prime}$ & & 4.16 & $\mathrm{dd}$ & $9.0,9.0$ & 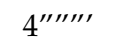 & & 4.16 & $\mathrm{dd}$ & $9.0,9.0$ \\
\hline $5^{\prime \prime \prime \prime \prime \prime \prime \prime \prime \prime \prime ~}$ & & 3.96 & $\mathrm{~m}$ & & 5 & & 3.96 & $\mathrm{~m}$ & \\
\hline \multirow[t]{2}{*}{$6^{\prime \prime \prime \prime \prime \prime \prime}$} & $\mathrm{a}$ & 4.48 & $\mathrm{dd}$ & $10.8,4.2$ & $6^{\prime \prime \prime \prime \prime \prime \prime}$ & a & 4.48 & $\mathrm{dd}$ & $11.4,4.2$ \\
\hline & $\mathrm{b}$ & 4.26 & $\mathrm{dd}$ & $10.8,6.0$ & & $b$ & 4.26 & $\mathrm{dd}$ & $11.4,5.4$ \\
\hline Qui & & & & & Qui & & & & \\
\hline "ו"ו"'ו"'ו" & & 4.97 & $\mathrm{~d}$ & 7.8 & $1^{\prime \prime \prime \prime \prime \prime \prime \prime \prime \prime ~}$ & & 5.05 & $\mathrm{~d}$ & 7.2 \\
\hline 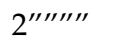 & & 4.00 & $\mathrm{dd}$ & $9.0,7.8$ & $2^{\prime \prime \prime \prime \prime \prime \prime \prime \prime \prime ~}$ & & 4.00 & $\mathrm{dd}$ & $9.6,7.2$ \\
\hline $3^{\prime \prime \prime \prime \prime \prime \prime \prime \prime ~}$ & & 4.05 & $\mathrm{dd}$ & $9.0,9.0$ & $3^{\prime \prime \prime \prime \prime \prime \prime \prime}$ & & 5.60 & $\mathrm{dd}$ & $9.6,9.6$ \\
\hline 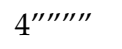 & & 3.62 & $\mathrm{dd}$ & $9.0,9.0$ & 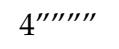 & & 5.05 & $\mathrm{dd}$ & $9.6,9.6$ \\
\hline $5^{\prime \prime \prime \prime \prime \prime \prime \prime}$ & & 3.66 & $\mathrm{dd}$ & $9.0,6.0$ & $5 " \prime \prime \prime \prime \prime \prime \prime$ & & 3.69 & $\mathrm{dd}$ & $9.6,6.0$ \\
\hline \multirow[t]{3}{*}{$6^{\prime \prime \prime \prime \prime \prime \prime \prime \prime}$} & & 1.55 & $\mathrm{~d}$ & 6.0 & $6^{\prime \prime \prime \prime \prime \prime \prime \prime}$ & & 1.24 & $\mathrm{~d}$ & 6.0 \\
\hline & & & & & $\begin{array}{c}3^{\prime \prime \prime \prime \prime \prime \prime}- \\
\text { OAc }\end{array}$ & & 1.96 & $\mathrm{~s}$ & \\
\hline & & & & & $\begin{array}{l}4^{\prime \prime \prime \prime \prime \prime \prime}- \\
\text { OAc }\end{array}$ & & 2.04 & $\mathrm{~s}$ & \\
\hline \multirow{2}{*}{\multicolumn{2}{|c|}{ Positions }} & 5 & & & & & 6 & & \\
\hline & & \multicolumn{2}{|c|}{$\delta_{\mathrm{H}}$} & $J(\mathrm{~Hz})$ & \multicolumn{2}{|c|}{ Positions } & \multicolumn{2}{|c|}{$\delta_{\mathrm{H}}$} & $J(\mathrm{~Hz})$ \\
\hline Xyl & & & & & Xyl & & & & \\
\hline $1^{\prime}$ & & 4.99 & $\mathrm{~d}$ & 7.4 & $1^{\prime}$ & & 4.97 & $\mathrm{~d}$ & 7.4 \\
\hline $2^{\prime}$ & & 3.96 & $\mathrm{dd}$ & $8.6,7.4$ & $2^{\prime}$ & & 3.94 & $\mathrm{dd}$ & $8.6,7.4$ \\
\hline $3^{\prime}$ & & 4.06 & $\mathrm{dd}$ & $8.6,8.6$ & $3^{\prime}$ & & 4.05 & $\mathrm{dd}$ & $8.6,8.6$ \\
\hline $4^{\prime}$ & & 4.20 & $\mathrm{~m}$ & & $4^{\prime}$ & & 4.18 & $\mathrm{~m}$ & \\
\hline \multirow[t]{2}{*}{$5^{\prime}$} & $\mathrm{a}$ & 4.35 & $\mathrm{dd}$ & $11.5,5.2$ & $5^{\prime}$ & $\mathrm{a}$ & 4.34 & $\mathrm{dd}$ & $11.6,4.9$ \\
\hline & $\mathrm{b}$ & 3.68 & $\mathrm{dd}$ & $11.5,10.0$ & & $\mathrm{~b}$ & 3.67 & $\mathrm{dd}$ & $11.6,11.0$ \\
\hline Glc (I) & & & & & Glc (I) & & & & \\
\hline $1^{\prime \prime}$ & & 6.22 & $\mathrm{~d}$ & 7.7 & $1^{\prime \prime}$ & & 6.17 & d & 7.1 \\
\hline $2^{\prime \prime}$ & & 4.18 & $\mathrm{dd}$ & $9.2,7.7$ & $2^{\prime \prime}$ & & 4.24 & $\mathrm{~m}$ & \\
\hline $3^{\prime \prime}$ & & 4.21 & $\mathrm{dd}$ & $9.2,9.2$ & $3^{\prime \prime}$ & & 4.25 & $\mathrm{~m}$ & \\
\hline $4^{\prime \prime}$ & & 4.55 & $\mathrm{dd}$ & $9.2,9.2$ & $4^{\prime \prime}$ & & 4.33 & $\mathrm{~m}$ & \\
\hline $5^{\prime \prime}$ & & 4.05 & $\mathrm{~m}$ & & $5^{\prime \prime}$ & & 4.11 & $\mathrm{~m}$ & \\
\hline \multirow[t]{2}{*}{$6^{\prime \prime}$} & $\mathrm{a}$ & 4.56 & br d & 10.8 & $6^{\prime \prime}$ & a & 4.53 & br d & 11.5 \\
\hline & $\mathrm{b}$ & 4.29 & $\mathrm{dd}$ & $10.8,3.9$ & & $\mathrm{~b}$ & 4.30 & $\mathrm{dd}$ & $11.5,3.6$ \\
\hline Glc (II) & & & & & Glc (II) & & & & \\
\hline $1^{\prime \prime \prime}$ & & 4.91 & $\mathrm{~d}$ & 7.8 & $1^{\prime \prime \prime}$ & & 5.28 & d & 7.8 \\
\hline $2^{\prime \prime \prime}$ & & 3.99 & $\mathrm{dd}$ & $9.1,7.8$ & $2^{\prime \prime \prime}$ & & 4.05 & $\mathrm{~m}$ & \\
\hline $3^{\prime \prime \prime}$ & & 4.25 & $\mathrm{dd}$ & $9.1,9.1$ & $3^{\prime \prime \prime}$ & & 4.14 & $\mathrm{dd}$ & $9.2,9.2$ \\
\hline $4^{\prime \prime \prime}$ & & 4.20 & $\mathrm{dd}$ & $9.1,9.1$ & $4^{\prime \prime \prime}$ & & 4.13 & $\mathrm{dd}$ & $9.2,9.2$ \\
\hline $5^{\prime \prime \prime}$ & & 3.76 & $\mathrm{~m}$ & & $5 " \prime$ & & 3.91 & $\mathrm{~m}$ & \\
\hline \multirow[t]{2}{*}{$6^{\prime \prime \prime}$} & $\mathrm{a}$ & 4.38 & $\mathrm{dd}$ & $12.3,2.2$ & $6^{\prime \prime \prime}$ & a & 4.44 & br d & 11.1 \\
\hline & $\mathrm{b}$ & 4.31 & br d & 12.3 & & $\mathrm{~b}$ & 4.25 & $\mathrm{dd}$ & $11.1,5.6$ \\
\hline Glc (III) & & & & & Glc (III) & & & & \\
\hline $1^{\prime \prime \prime \prime}$ & & 5.26 & $\mathrm{~d}$ & 7.8 & $1^{\prime \prime \prime \prime}$ & & 4.99 & d & 7.7 \\
\hline $2^{\prime \prime \prime \prime}$ & & 4.03 & $\mathrm{dd}$ & $8.5,7.8$ & $2^{\prime \prime \prime \prime}$ & & 4.06 & $\mathrm{dd}$ & $8.8,7.7$ \\
\hline $3^{\prime \prime \prime \prime}$ & & 4.17 & $\mathrm{~m}$ & & $3^{\prime \prime \prime \prime}$ & & 4.22 & $\mathrm{dd}$ & $8.8,8.8$ \\
\hline $4^{\prime \prime \prime \prime}$ & & 4.18 & $\mathrm{~m}$ & & $4^{\prime \prime \prime \prime}$ & & 3.99 & $\mathrm{dd}$ & $8.8,8.8$ \\
\hline $5^{\prime \prime \prime \prime}$ & & 3.90 & $\mathrm{~m}$ & & $5^{\prime \prime \prime \prime}$ & & 3.89 & $\mathrm{~m}$ & \\
\hline \multirow[t]{2}{*}{ 6"'” } & $\mathrm{a}$ & 4.51 & $\mathrm{dd}$ & $12.1,2.2$ & $6^{\prime \prime \prime \prime}$ & $\mathrm{a}$ & 4.92 & br d & 11.2 \\
\hline & $\mathrm{b}$ & 4.34 & br d & 12.1 & & $\mathrm{~b}$ & 4.68 & $\mathrm{dd}$ & $11.2,5.8$ \\
\hline
\end{tabular}


Table 2. Cont.

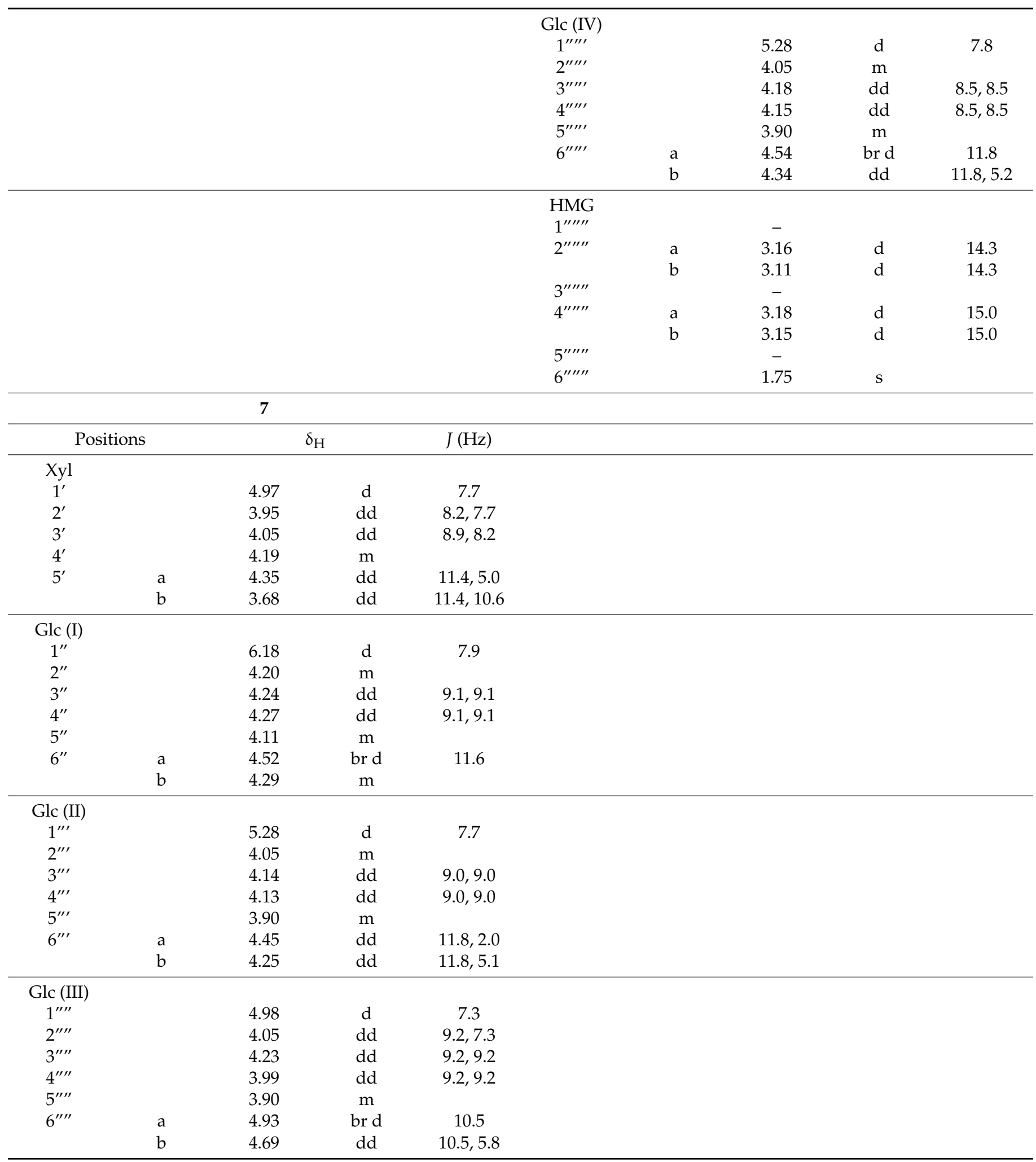


Table 2. Cont.

\begin{tabular}{|c|c|c|c|c|}
\hline \multicolumn{5}{|c|}{ Glc (IV) } \\
\hline $1^{\prime \prime \prime \prime \prime}$ & & 5.29 & d & 7.6 \\
\hline $2^{\prime \prime \prime \prime \prime}$ & & 4.05 & $\mathrm{~m}$ & \\
\hline $3^{\prime \prime \prime \prime \prime \prime}$ & & 4.17 & $\mathrm{dd}$ & $8.6,8.6$ \\
\hline $4^{\prime \prime \prime \prime \prime}$ & & 4.18 & $\mathrm{dd}$ & $8.6,8.6$ \\
\hline $5^{\prime \prime \prime \prime \prime \prime}$ & & 3.90 & $\mathrm{~m}$ & \\
\hline \multirow[t]{2}{*}{$6^{\prime \prime \prime \prime \prime}$} & $\mathrm{a}$ & 4.52 & br d & 11.7 \\
\hline & $b$ & 4.33 & $\mathrm{dd}$ & $11.7,4.8$ \\
\hline \multicolumn{5}{|l|}{ HMG } \\
\hline $1^{\prime \prime \prime \prime \prime \prime}$ & & - & & \\
\hline \multirow[t]{2}{*}{$2^{\prime \prime \prime \prime \prime \prime}$} & $\mathrm{a}$ & 3.18 & $\mathrm{~d}$ & 14.3 \\
\hline & $\mathrm{b}$ & 3.12 & $\mathrm{~d}$ & 14.3 \\
\hline $3^{\prime \prime \prime \prime \prime \prime}$ & & - & & \\
\hline \multirow[t]{2}{*}{$4^{\prime \prime \prime \prime \prime \prime \prime}$} & $\mathrm{a}$ & 3.19 & $\mathrm{~d}$ & 15.1 \\
\hline & $\mathrm{b}$ & 3.15 & $\mathrm{~d}$ & 15.1 \\
\hline $5^{\prime \prime \prime \prime \prime \prime}$ & & - & & \\
\hline $6^{\prime \prime \prime \prime \prime \prime}$ & & 1.75 & $\mathrm{~s}$ & \\
\hline
\end{tabular}

The ${ }^{1} \mathrm{H}-\mathrm{NMR}$ spectra of $1-7$ were recorded at $600 \mathrm{MHz}$ in $\mathrm{C}_{5} \mathrm{D}_{5} \mathrm{~N}$. * Signals are overlapped with water signal.

Table $3 .{ }^{13} \mathrm{C}-\mathrm{NMR}$ spectral data for $1-7$.

\begin{tabular}{|c|c|c|c|c|c|c|c|}
\hline Positions & 1 & 2 & 3 & 4 & 5 & 6 & 7 \\
\hline 1 & 38.1 & 38.2 & 38.1 & 38.2 & 38.9 & 38.8 & 38.9 \\
\hline 2 & 25.3 & 25.3 & 25.3 & 25.3 & 26.3 & 26.3 & 26.3 \\
\hline 3 & 84.4 & 84.4 & 84.5 & 84.4 & 85.0 & 85.0 & 85.0 \\
\hline 4 & 55.0 & 55.1 & 55.1 & 55.1 & 53.3 & 53.3 & 53.3 \\
\hline 5 & 48.9 & 49.0 & 48.8 & 49.0 & 52.1 & 52.1 & 52.2 \\
\hline 6 & 20.5 & 20.7 & 20.6 & 20.7 & 21.3 & 21.3 & 21.3 \\
\hline 7 & 33.0 & 33.1 & 32.8 & 33.1 & 33.1 & 32.8 & 33.1 \\
\hline 8 & 40.3 & 40.3 & 40.3 & 40.3 & 40.4 & 40.2 & 40.3 \\
\hline 9 & 46.9 & 47.0 & 46.9 & 47.0 & 47.4 & 48.3 & 47.4 \\
\hline 10 & 36.2 & 36.3 & 36.3 & 36.3 & 36.7 & 36.7 & 36.7 \\
\hline 11 & 23.7 & 23.7 & 23.7 & 23.7 & 23.8 & 23.8 & 23.8 \\
\hline 12 & 121.9 & 121.8 & 122.1 & 121.8 & 122.3 & 122.7 & 122.5 \\
\hline 13 & 144.5 & 144.5 & 144.5 & 144.5 & 144.5 & 144.0 & 144.4 \\
\hline 14 & 42.1 & 42.2 & 42.1 & 42.2 & 42.0 & 42.1 & 42.0 \\
\hline 15 & 36.2 & 36.4 & 36.2 & 36.4 & 36.0 & 28.2 & 36.0 \\
\hline 16 & 74.2 & 74.0 & 74.0 & 74.0 & 74.1 & 23.1 & 74.0 \\
\hline 17 & 49.2 & 49.3 & 49.2 & 49.3 & 49.0 & 47.0 & 49.0 \\
\hline 18 & 41.7 & 41.9 & 41.6 & 41.9 & 41.2 & 41.6 & 41.2 \\
\hline 19 & 47.5 & 47.7 & 47.3 & 47.7 & 47.1 & 46.2 & 47.1 \\
\hline 20 & 30.6 & 30.6 & 30.7 & 30.6 & 30.7 & 30.7 & 30.7 \\
\hline 21 & 36.0 & 36.1 & 36.0 & 36.1 & 35.8 & 33.9 & 35.8 \\
\hline 22 & 31.6 & 31.4 & 31.9 & 31.4 & 32.0 & 32.4 & 32.0 \\
\hline 23 & 210.1 & 210.2 & 210.2 & 210.2 & 180.3 & 180.4 & 180.4 \\
\hline 24 & 11.1 & 11.2 & 11.1 & 11.2 & 12.6 & 12.5 & 12.6 \\
\hline 25 & 15.9 & 15.9 & 15.8 & 15.9 & 16.1 & 16.0 & 16.1 \\
\hline 26 & 17.4 & 17.4 & 17.4 & 17.4 & 17.4 & 17.3 & 17.4 \\
\hline 27 & 27.1 & 27.2 & 27.0 & 27.2 & 27.1 & 26.0 & 27.1 \\
\hline 28 & 175.9 & 176.0 & 176.0 & 176.0 & 175.9 & 176.3 & 175.8 \\
\hline 29 & 33.1 & 33.0 & 33.1 & 33.0 & 33.1 & 33.0 & 33.1 \\
\hline \multirow[t]{2}{*}{30} & 24.4 & 24.4 & 24.5 & 24.4 & 24.5 & 23.7 & 24.6 \\
\hline & GlcUA & GlcUA & GlcUA & GlcUA & Xyl & Xyl & Xyl \\
\hline $1^{\prime}$ & 103.9 & 103.9 & 103.9 & 103.9 & 106.2 & 106.2 & 106.2 \\
\hline $2^{\prime}$ & 78.6 & 78.7 & 78.4 & 78.4 & 75.2 & 75.2 & 75.2 \\
\hline $3^{\prime}$ & 86.0 & 86.0 & 86.1 & 86.1 & 78.0 & 78.0 & 78.0 \\
\hline $4^{\prime}$ & 71.3 & 71.3 & 71.3 & 71.3 & 71.0 & 71.1 & 71.0 \\
\hline
\end{tabular}


Table 3. Cont.

\begin{tabular}{|c|c|c|c|c|c|c|c|}
\hline Positions & 1 & 2 & 3 & 4 & 5 & 6 & 7 \\
\hline $5^{\prime}$ & 77.2 & 77.2 & 77.3 & 77.3 & 67.0 & 67.0 & 67.0 \\
\hline \multirow[t]{2}{*}{$6^{\prime}$} & 171.7 & 171.7 & 171.7 & 171.7 & & & \\
\hline & Gal & Gal & Gal & Gal & Glc (I) & Glc (I) & Glc (I) \\
\hline $1^{\prime \prime}$ & 104.2 & 104.2 & 104.1 & 104.1 & 95.7 & 94.8 & 94.9 \\
\hline $2^{\prime \prime}$ & 73.7 & 73.7 & 73.6 & 73.6 & 74.0 & 73.0 & 73.0 \\
\hline $3^{\prime \prime}$ & 75.4 & 75.2 & 75.5 & 75.5 & 78.5 & 88.2 & 88.0 \\
\hline $4^{\prime \prime}$ & 70.1 & 70.1 & 70.1 & 70.1 & 70.2 & 69.1 & 69.1 \\
\hline $5^{\prime \prime}$ & 76.6 & 76.6 & 76.5 & 76.6 & 77.1 & 76.9 & 76.9 \\
\hline \multirow[t]{2}{*}{$6^{\prime \prime}$} & 61.6 & 61.6 & 61.6 & 61.6 & 69.1 & 68.9 & 69.0 \\
\hline & Xyl (I) & Xyl (I) & Xyl (I) & Xyl (I) & Glc (II) & Glc (II) & Glc (II) \\
\hline $1^{\prime \prime \prime}$ & 105.0 & 105.0 & 105.0 & 105.0 & 102.7 & 105.7 & 105.7 \\
\hline $2^{\prime \prime \prime}$ & 75.3 & 75.3 & 75.3 & 75.2 & 84.4 & 75.6 & 75.6 \\
\hline $3^{\prime \prime \prime}$ & 78.5 & 78.6 & 78.6 & 78.6 & 78.1 & 77.9 & 78.1 \\
\hline $4^{\prime \prime \prime}$ & 70.8 & 70.8 & 70.8 & 70.8 & 70.5 & 71.3 & 71.3 \\
\hline $5^{\prime \prime \prime}$ & 67.3 & 67.3 & 67.3 & 67.3 & 78.3 & 78.5 & 78.5 \\
\hline \multirow[t]{2}{*}{$6^{\prime \prime \prime}$} & & & & & 62.0 & 62.3 & 62.3 \\
\hline & Fuc & Fuc & Fuc & Fuc & Glc (III) & Glc (III) & Glc (III) \\
\hline $1^{\prime \prime \prime \prime}$ & 94.8 & 94.7 & 94.6 & 94.5 & 106.1 & 102.5 & 102.5 \\
\hline $2^{\prime \prime \prime \prime}$ & 75.2 & 73.8 & 74.4 & 74.3 & 76.3 & 83.3 & 83.2 \\
\hline $3^{\prime \prime \prime \prime}$ & 75.9 & 76.8 & 76.8 & 76.2 & 78.1 & 77.7 & 77.7 \\
\hline $4^{\prime \prime \prime \prime}$ & 83.4 & 84.0 & 84.0 & 83.5 & 70.9 & 71.0 & 70.9 \\
\hline $5^{\prime \prime \prime \prime}$ & 71.5 & 71.8 & 71.6 & 71.4 & 78.6 & 75.0 & 75.0 \\
\hline \multirow[t]{2}{*}{$6^{\prime \prime \prime \prime}$} & 17.1 & 17.1 & 17.1 & 17.0 & 62.0 & 64.4 & 64.3 \\
\hline & Rha & Rha & Rha & Rha & & Glc (IV) & Glc (IV) \\
\hline $1^{\prime \prime \prime \prime \prime \prime}$ & 101.7 & 100.9 & 101.2 & 101.2 & & 105.6 & 105.7 \\
\hline $2^{\prime \prime \prime \prime \prime}$ & 70.8 & 71.2 & 71.8 & 71.7 & & 76.2 & 76.2 \\
\hline $3^{\prime \prime \prime \prime \prime}$ & 82.3 & 83.1 & 72.4 & 72.3 & & 78.1 & 78.0 \\
\hline $4^{\prime \prime \prime \prime \prime \prime}$ & 78.2 & 78.2 & 83.5 & 83.4 & & 71.2 & 71.1 \\
\hline $5^{\prime \prime \prime \prime \prime \prime}$ & 68.9 & 68.3 & 68.3 & 68.3 & & 78.4 & 78.4 \\
\hline \multirow[t]{2}{*}{$6^{\prime \prime \prime \prime \prime}$} & 18.9 & 18.8 & 18.6 & 18.5 & & 62.5 & 62.4 \\
\hline & Glc & Glc & Xyl (II) & Xyl (II) & & HMG & HMG \\
\hline $1^{\prime \prime \prime \prime \prime \prime \prime \prime}$ & 105.2 & 105.3 & 106.2 & 106.1 & & 171.7 & 171.7 \\
\hline $2^{\prime \prime \prime \prime \prime \prime}$ & 75.4 & 75.1 & 74.8 & 74.8 & & 46.6 & 46.5 \\
\hline $3^{\prime \prime \prime \prime \prime \prime}$ & 78.3 & 78.1 & 88.2 & 88.3 & & 70.0 & 70.0 \\
\hline $4^{\prime \prime \prime \prime \prime \prime}$ & 71.7 & 71.7 & 69.3 & 69.3 & & 46.3 & 46.3 \\
\hline $5^{\prime \prime \prime \prime \prime \prime}$ & 78.4 & 75.2 & 66.7 & 66.6 & & 174.6 & 174.7 \\
\hline \multirow[t]{2}{*}{$6^{\prime \prime \prime \prime \prime \prime}$} & 62.6 & 64.4 & & & & 28.2 & 28.2 \\
\hline & Xyl (II) & Xyl (II) & Glc & Glc & & & \\
\hline $1^{\prime \prime \prime \prime \prime \prime \prime \prime}$ & 104.9 & 104.8 & 105.5 & 105.5 & & & \\
\hline $2^{\prime \prime \prime \prime \prime \prime \prime}$ & 75.6 & 75.7 & 75.4 & 75.3 & & & \\
\hline 3'ו"'ו"', & 79.1 & 79.1 & 78.3 & 78.3 & & & \\
\hline $4^{\prime \prime \prime \prime \prime \prime \prime}$ & 71.2 & 71.2 & 71.5 & 71.5 & & & \\
\hline $5^{\prime \prime \prime \prime \prime \prime \prime \prime}$ & 67.1 & 67.1 & 78.6 & 78.6 & & & \\
\hline \multirow[t]{2}{*}{$6^{\prime \prime \prime \prime \prime \prime \prime \prime \prime \prime ~}$} & & & 62.5 & 62.4 & & & \\
\hline & Qui & Qui & Qui & Qui & & & \\
\hline $1^{\prime \prime \prime \prime \prime \prime \prime \prime \prime \prime \prime ~}$ & 106.3 & 106.7 & 106.7 & 105.7 & & & \\
\hline $2^{\prime \prime \prime \prime \prime \prime \prime \prime}$ & 75.7 & 75.8 & 75.8 & 73.1 & & & \\
\hline $3^{\prime \prime \prime \prime \prime \prime \prime \prime \prime \prime ~}$ & 78.1 & 78.2 & 78.4 & 76.3 & & & \\
\hline $4^{\prime \prime \prime \prime \prime \prime \prime \prime}$ & 76.7 & 76.7 & 76.6 & 74.4 & & & \\
\hline $5^{\prime \prime \prime \prime \prime \prime \prime \prime}$ & 73.1 & 73.2 & 73.2 & 70.2 & & & \\
\hline \multirow[t]{7}{*}{$6^{\prime \prime \prime \prime \prime \prime \prime \prime \prime \prime ~}$} & 18.5 & 18.5 & 18.5 & 17.7 & & & \\
\hline & & $6^{\prime \prime \prime \prime \prime-O A c}$ & & $3^{\prime \prime \prime \prime \prime \prime \prime-O A c ~}$ & & & \\
\hline & & 21.0 & & 20.6 & & & \\
\hline & & 170.9 & & 170.4 & & & \\
\hline & & & & $4 " \prime \prime \prime \prime \prime-O A c$ & & & \\
\hline & & & & 20.7 & & & \\
\hline & & & & 170.1 & & & \\
\hline
\end{tabular}


Compound 2: Amorphous solid; $[\alpha]_{\mathrm{D}}{ }^{25}-16.7(c=0.05, \mathrm{MeOH})$; IR (film) $v_{\max }: 3397$ $(\mathrm{OH}), 2933(\mathrm{CH}), 1730(\mathrm{C}=\mathrm{O}) \mathrm{cm}^{-1}$; HR-ESI-TOF-MS m/z: $1753.7300[\mathrm{M}+\mathrm{Na}]^{+}$(calculated for $\mathrm{C}_{78} \mathrm{H}_{122} \mathrm{NaO}_{42}$ : 1753.7308). ${ }^{1} \mathrm{H}-\mathrm{NMR}$ spectral data for the aglycone moiety $(600 \mathrm{MHz}$, $\left.\mathrm{C}_{5} \mathrm{D}_{5} \mathrm{~N}\right): \delta_{\mathrm{H}} 9.92(1 \mathrm{H}, \mathrm{s}, \mathrm{H}-23), 5.53(1 \mathrm{H}, \mathrm{m}, \mathrm{H}-12), 5.12(1 \mathrm{H}, \mathrm{br} \mathrm{s}, \mathrm{H}-16), 4.09(1 \mathrm{H}, \mathrm{m}, \mathrm{H}-3)$, $1.72(3 \mathrm{H}, \mathrm{s}, \mathrm{Me}-27), 1.49$ (3H, s, Me-24), 1.17 (3H, s, Me-26), $0.93(3 \mathrm{H}, \mathrm{s}, \mathrm{Me}-30), 0.90(3 \mathrm{H}$, $\mathrm{s}, \mathrm{Me}-29), 0.89(3 \mathrm{H}, \mathrm{s}, \mathrm{Me}-25) .{ }^{1} \mathrm{H}-\mathrm{NMR}$ spectral data for the sugar and acyl moieties, see Table 2. ${ }^{13} \mathrm{C}-\mathrm{NMR}$ spectral data, see Table 3. NMR spectral data, see Supplementary Materials.

Compound 3: Amorphous solid; $[\alpha]_{\mathrm{D}}^{25}-5.8(c=0.05, \mathrm{MeOH})$; IR (film) $\gamma_{\max }: 3398$ $(\mathrm{OH}), 2925(\mathrm{CH}), 1730(\mathrm{C}=\mathrm{O}) \mathrm{cm}^{-1}$; HR-ESI-TOF-MS m/z: $1711.7191[\mathrm{M}+\mathrm{Na}]^{+}$(calculated for $\mathrm{C}_{76} \mathrm{H}_{120} \mathrm{NaO}_{41}$ : 1711.7203). ${ }^{1} \mathrm{H}-\mathrm{NMR}$ spectral data for the aglycone moiety $(600 \mathrm{MHz}$, $\left.\mathrm{C}_{5} \mathrm{D}_{5} \mathrm{~N}\right): \delta_{\mathrm{H}} 9.91(1 \mathrm{H}, \mathrm{s}, \mathrm{H}-23), 5.53(1 \mathrm{H}, \mathrm{m}, \mathrm{H}-12), 5.15(1 \mathrm{H}, \mathrm{br} \mathrm{s}, \mathrm{H}-16), 4.05(1 \mathrm{H}, \mathrm{m}, \mathrm{H}-3)$, $1.73(3 \mathrm{H}, \mathrm{s}, \mathrm{Me}-27), 1.44$ (3H, s, Me-24), 1.03 (3H, s, Me-26), 0.96 (3H, s, Me-30), $0.93(3 \mathrm{H}$, s, Me-29), $0.81(3 \mathrm{H}, \mathrm{s}, \mathrm{Me}-25) .{ }^{1} \mathrm{H}-\mathrm{NMR}$ spectral data for the sugar moiety, see Table 2. ${ }^{13}$ C-NMR spectral data, see Table 3. NMR spectral data, see Supplementary Materials.

Compound 4: Amorphous solid; $[\alpha]_{D}{ }^{25}+3.6(c=0.05, \mathrm{MeOH}) ; \mathrm{IR}($ film $) v_{\max }: 3398$ $(\mathrm{OH}), 2929(\mathrm{CH}), 1726(\mathrm{C}=\mathrm{O}) \mathrm{cm}^{-1}$; HR-ESI-TOF-MS m/z: $1771.7439[\mathrm{M}-\mathrm{H}]^{-}$(calculated for $\mathrm{C}_{80} \mathrm{H}_{123} \mathrm{O}_{43}$ : 1771.7438). ${ }^{1} \mathrm{H}-\mathrm{NMR}$ spectral data for the aglycone moiety $(600 \mathrm{MHz}$, $\left.\mathrm{C}_{5} \mathrm{D}_{5} \mathrm{~N}\right): \delta_{\mathrm{H}} 9.91(1 \mathrm{H}, \mathrm{s}, \mathrm{H}-23), 5.53(1 \mathrm{H}, \mathrm{m}, \mathrm{H}-12), 5.12(1 \mathrm{H}, \mathrm{br} \mathrm{s}, \mathrm{H}-16), 4.05(1 \mathrm{H}, \mathrm{m}, \mathrm{H}-3)$, $1.74(3 \mathrm{H}, \mathrm{s}, \mathrm{Me}-26), 1.73$ (3H, s, Me-27), 1.44 (3H, s, Me-24), 0.97 (3H, s, Me-30), $0.93(3 \mathrm{H}$, $\mathrm{s}, \mathrm{Me}-29), 0.81$ (3H, s, Me-25). ${ }^{1} \mathrm{H}-\mathrm{NMR}$ spectral data for the sugar and acyl moieties, see Table 2. ${ }^{13} \mathrm{C}-\mathrm{NMR}$ spectral data, see Table 3. NMR spectral data, see Supplementary Materials.

Compound 5: Amorphous solid; $[\alpha]_{\mathrm{D}}{ }^{25}-76.5(c=0.05, \mathrm{MeOH})$; IR (film) $v_{\max }: 3358$ $(\mathrm{OH}), 2925(\mathrm{CH}), 1712(\mathrm{C}=\mathrm{O}) \mathrm{cm}^{-1}$; HR-ESI-TOF-MS m/z: $1143.5189[\mathrm{M}+\mathrm{Na}]^{+}\left(\mathrm{cal}^{-}\right.$ culated for $\mathrm{C}_{53} \mathrm{H}_{84} \mathrm{NaO}_{25}$ : 1143.5199). ${ }^{1} \mathrm{H}-\mathrm{NMR}$ spectral data for the aglycone moiety $\left(600 \mathrm{MHz}, \mathrm{C}_{5} \mathrm{D}_{5} \mathrm{~N}\right): \delta_{\mathrm{H}} 5.59(1 \mathrm{H}, \mathrm{dd}, J=3.4,3.4 \mathrm{~Hz}, \mathrm{H}-12), 5.23(1 \mathrm{H}, \mathrm{br} \mathrm{s}, \mathrm{H}-16), 4.64(1 \mathrm{H}$, $\mathrm{dd}, J=12.0,4.4 \mathrm{~Hz}, \mathrm{H}-3), 1.76$ (3H, s, Me-27), 1.56 (3H, s, Me-24), 1.11 (3H, s, Me-26), 0.99 $(3 \mathrm{H}, \mathrm{s}, \mathrm{Me}-30), 0.98$ (3H, s, Me-25), $0.92(3 \mathrm{H}, \mathrm{s}, \mathrm{Me}-29) .{ }^{1} \mathrm{H}-\mathrm{NMR}$ spectral data for the sugar moiety, see Table 2. ${ }^{13} \mathrm{C}-\mathrm{NMR}$ spectral data, see Table 3. NMR spectral data, see Supplementary Materials.

Compound 6: Amorphous solid; $[\alpha]_{\mathrm{D}}{ }^{25}+8.5(c=0.05, \mathrm{MeOH}) ; \mathrm{IR}$ (film) $v_{\max }: 3377$ $(\mathrm{OH}), 2925(\mathrm{CH}), 1717(\mathrm{C}=\mathrm{O}) \mathrm{cm}^{-1}$; HR-ESI-TOF-MS m/z: $1433.6193[\mathrm{M}+\mathrm{Na}]^{+}$(calculated for $\mathrm{C}_{65} \mathrm{H}_{102} \mathrm{NaO}_{33}$ : 1433.6201). ${ }^{1} \mathrm{H}-\mathrm{NMR}$ spectral data for the aglycone moiety $(600 \mathrm{MHz}$, $\left.\mathrm{C}_{5} \mathrm{D}_{5} \mathrm{~N}\right): \delta_{\mathrm{H}} 5.39(1 \mathrm{H}, \mathrm{dd}, J=3.5,3.5 \mathrm{~Hz}, \mathrm{H}-12), 4.60(1 \mathrm{H}, \mathrm{dd}, J=11.8,4.3 \mathrm{~Hz}, \mathrm{H}-3), 1.55(3 \mathrm{H}$, s, Me-24), 1.17 (3H, s, Me-27), 1.04 (3H, s, Me-26), 0.95 (3H, s, Me-25), 0.91 (3H, s, Me-30), $0.85(3 \mathrm{H}, \mathrm{s}, \mathrm{Me}-29) .{ }^{1} \mathrm{H}-\mathrm{NMR}$ spectral data for the sugar and acyl moieties, see Table 2. ${ }^{13} \mathrm{C}$-NMR spectral data, see Table 3. NMR spectral data, see Supplementary Materials.

Compound 7: Amorphous solid; $[\alpha]_{\mathrm{D}}{ }^{25}+4.4(c=0.05, \mathrm{MeOH})$; IR (film) $v_{\max }: 3377$ $(\mathrm{OH}), 2925(\mathrm{CH}), 1730(\mathrm{C}=\mathrm{O}) \mathrm{cm}^{-1}$; HR-ESI-TOF-MS m/z: $1449.6165[\mathrm{M}+\mathrm{Na}]^{+}$(calculated for $\mathrm{C}_{65} \mathrm{H}_{102} \mathrm{NaO}_{34}$ : 1449.6150). ${ }^{1} \mathrm{H}-\mathrm{NMR}$ spectral data for the aglycone moiety $(600 \mathrm{MHz}$, $\left.\mathrm{C}_{5} \mathrm{D}_{5} \mathrm{~N}\right): \delta_{\mathrm{H}} 5.57(1 \mathrm{H}, \mathrm{m}, \mathrm{H}-12), 5.20(1 \mathrm{H}, \mathrm{br} \mathrm{s}, \mathrm{H}-16), 4.64(1 \mathrm{H}, \mathrm{dd}, J=11.9,4.4 \mathrm{~Hz}, \mathrm{H}-3), 1.75$ $(3 \mathrm{H}, \mathrm{s}, \mathrm{Me}-27), 1.56$ (3H, s, Me-24), 1.08 (3H, s, Me-26), 1.05 (3H, s, Me-30), 0.99 (3H, s, Me25), $0.93(3 \mathrm{H}, \mathrm{s}, \mathrm{Me}-29) .{ }^{1} \mathrm{H}-\mathrm{NMR}$ spectral data for the sugar and acyl moieties, see Table 2. ${ }^{13}$ C-NMR spectral data, see Table 3. NMR spectral data, see Supplementary Materials.

Alkaline treatment of $\mathbf{1}$ followed acid hydrolysis: Compound $\mathbf{1}(11 \mathrm{mg})$ was treated with $1 \mathrm{M} \mathrm{KOH}$ in $\mathrm{MeOH}$ at $80^{\circ} \mathrm{C}$ for $90 \mathrm{~min}$. The reaction solution was neutralized by passing through an Amberlite 120B (Organo, Tokyo, Japan) column eluted with $\mathrm{EtOH}$, and was separated by ODS silica gel CC eluted with $\mathrm{MeCN} / \mathrm{H}_{2} \mathrm{O}(2: 3)$ to obtain 8 (5.8 mg) and a residue. The residue was dealt with $1 \mathrm{M} \mathrm{HCl}$ (dioxane $/ \mathrm{H}_{2} \mathrm{O}, 1: 1$ ) at $95{ }^{\circ} \mathrm{C}$ for $2 \mathrm{~h}$. The reaction mixture was neutralized by passing through an Amberlite IRA96SB (Organo) column eluted with $\mathrm{EtOH}$ to afford a sugar fraction. The sugar fraction was analyzed by HPLC under the following conditions: solvent, $\mathrm{MeCN} / \mathrm{H}_{2} \mathrm{O}$ (17:3); flow rate, $0.5 \mathrm{~mL} / \mathrm{min}$; column temperature, $40{ }^{\circ} \mathrm{C}$; pump, Tosoh DP-8020; column, Capcell Pak $\mathrm{NH}_{2}$ (4.6 mm i.d. 
$\times 250 \mathrm{~mm}, 5 \mu \mathrm{m}$; Shiseido, Tokyo, Japan); detector, Shodex OR2 (Showa-Denko, Tokyo, Japan). D-fucose, D-quinovose, D-xylose, D-glucose, and L-rhamnose were identified by comparing their retention times $\left(t_{R}\right)$ and optical rotations with those of authentic samples: D-fucose (12.69, positive optical rotation), D-quinovose (13.06, positive optical rotation), D-xylose (14.37, positive optical rotation), D-glucose (19.66, positive optical rotation), and L-rhamnose (12.17, negative optical rotation).

\subsection{Cell Culture and Cytotoxic Activity Assay}

HL-60 cells were maintained in RPMI-1640 medium, and A549 cells and SBC-3 cells in MEM containing 10\% heat-inactivated FBS supplemented with L-glutamine, 100 unit $/ \mathrm{mL}$ penicillin $\mathrm{G}$ sodium salt, and $100 \mu \mathrm{g} / \mathrm{mL}$ streptomycin sulfate. The cells were incubated at $37^{\circ} \mathrm{C}$ in a $5 \% \mathrm{CO}_{2} /$ air atmosphere. HL-60 cells $\left(4 \times 10^{4}\right.$ cells $\left./ \mathrm{mL}\right)$, A549 cells $\left(1 \times 10^{4}\right.$ cells $\left./ \mathrm{mL}\right)$, and SBC-3 cells $\left(2 \times 10^{4}\right.$ cells $\left./ \mathrm{mL}\right)$ were seeded in a 96-well flatbottomed plate. After pre-incubation for $24 \mathrm{~h}, 4 \mu \mathrm{L}$ of EtOH/ $\mathrm{H}_{2} \mathrm{O}$ (1:1) solution containing each test sample was added and incubated for $72 \mathrm{~h} ; 4 \mu \mathrm{L}$ of $\mathrm{EtOH} / \mathrm{H}_{2} \mathrm{O}(1: 1)$ solution was added to the control cells. Cell viability was evaluated using the modified MTT reduction assay method. After terminating the cell culture, $10 \mu \mathrm{L}$ of MTT solution $(5 \mathrm{mg} / \mathrm{mL}$ in PBS) was added to each well, and the plate was further incubated. After $4 \mathrm{~h}$ of incubation, MTT formazan was dissolved in dimethyl sulfoxide (DMSO) and the absorbance was measured at $405 \mathrm{~nm}$. A dose-response curve was plotted for 1-5, 9, and 10, which inhibited cell growth by more than $50 \%$ at sample concentrations of $50 \mu \mathrm{M}$, and the concentrations at which $50 \%$ inhibition $\left(\mathrm{IC}_{50}\right)$ of cell growth occurred were calculated. The cell growth inhibition of SBC- 3 cells $\left(5 \times 10^{4}\right.$ cells $\left./ \mathrm{mL}\right)$ treated with $\mathbf{1}$ for $24 \mathrm{~h}$ was evaluated using the same method as above.

\subsection{Apoptosis Induction Assay}

SBC-3 cells $\left(5 \times 10^{5}\right.$ cells $\left./ \mathrm{mL}\right)$ were harvested in a 6-well flat-bottomed plate and pre-incubated for $24 \mathrm{~h}$. Then, SBC-3 cells were treated with either EtOH/ $\mathrm{H}_{2} \mathrm{O}$ (1:1) (control), $10 \mu \mathrm{M}$ of cisplatin, or $10 \mu \mathrm{M}$ of 1 . After $24 \mathrm{~h}$ of incubation, SBC-3 cells were detached using TrypLE Select and stained with $1 \times$ Annexin V binding buffer containing Annexin V-FITC and $\mathrm{PI}$ at $28^{\circ} \mathrm{C}$ for $15 \mathrm{~min}$ according to the manufacturer's protocol (Nacalai Tesque). Flow cytometry analysis was conducted using a BD FACSCelesta flow cytometer (BD Biosciences, Franklin Lakes, NJ, USA).

\subsection{Cell Cycle Distrubution Analysis}

SBC-3 cells $\left(5 \times 10^{5}\right.$ cells $\left./ \mathrm{mL}\right)$ were cultured in a 6-well flat-bottomed plate and treated with either $\mathrm{EtOH} / \mathrm{H}_{2} \mathrm{O}$ (1:1) (control), $10 \mu \mathrm{M}$ of cisplatin, or $10 \mu \mathrm{M}$ of 1 . After $12 \mathrm{~h}$ or $24 \mathrm{~h}$ of incubation, SBC-3 cells were detached using TrypLE Select and fixed with EtOH/PBS (7:3) at $-20{ }^{\circ} \mathrm{C}$ overnight. After removal of EtOH/PBS (7:3), the cells were stained with FxCycle PI/RNase Staining Solution (Thermo Fisher Scientific) at $28^{\circ} \mathrm{C}$ for $15 \mathrm{~min}$. Cell cycle distribution was analyzed using a BD FACSCelesta flow cytometer.

\subsection{Western Blotting Analysis}

SBC- 3 cells $\left(5 \times 10^{5}\right.$ cells $\left./ \mathrm{mL}\right)$ were seeded into a 6-well flat-bottomed plate and treated with either $\mathrm{EtOH} / \mathrm{H}_{2} \mathrm{O}$ (1:1) (control), $10 \mu \mathrm{M}$ of cisplatin, or $10 \mu \mathrm{M}$ of 1 . After $24 \mathrm{~h}$ of incubation, SBC-3 cells were detached using TrypLE Select. The SBC-3 cell proteins were extracted on ice for $30 \mathrm{~min}$ using RIPA buffer (FUJIFILM Wako Pure Chemical) containing Pierce Protease and Phosphatase inhibitor Mini Tablet (Thermo Fisher Scientific). Then, SBC-3 cells were centrifuged at $10,000 \times g$ for $30 \mathrm{~min}$, and the supernatant protein solution was collected. Protein quantification was performed using the TaKaRa BCA Protein Assay Kit (Takara Bio, Shiga, Japan). Then, sample protein solutions were loaded on NuPAGE $4-12 \%$ Bis-Tris Gel (Thermo Fisher Scientific), and electrophoresis was performed using a WSE-1165 RapidasMinislab electrophoresis tank (ATTO, Tokyo, Japan). Proteins were transferred from the gel to a polyvinylidene difluoride (PVDF) membrane using a Protein 
Transfer Kit for Semidry (COSMO BIO, Tokyo, Japan) and a WSE-4025HorizeBLOT 2M (ATTO). The PVDF membrane was then blocked using a Blocking One solution (Nacalai Tesque) at $28{ }^{\circ} \mathrm{C}$. After $30 \mathrm{~min}$, the PVDF membrane was reacted with the following primary antibodies dissolved in Can Get Signal Immunoreaction Enhancer Solution 1 (TOYOBO, Osaka, Japan) at $4^{\circ} \mathrm{C}$ overnight: $\beta$-actin (8H10D10 Mouse mAb, \#3700, 1:1000; Cell Signaling Technology, Danvers, MA, USA), Caspase-3 (3G2 Mouse mAb, \#9668, 1:1000; Cell Signaling Technology), Caspase-8 (1C12 Mouse mAb, \#9746, 1:1000; Cell Signaling Technology), Caspase-9 (C9 Mouse mAb, \#9508, 1:2000; Cell Signaling Technology), PARP (46D11 Rabbit mAb, \#9532, 1:1000; Cell Signaling Technology), Bax (2D2 Mouse mAb, \#89477, 1:1000; Cell Signaling Technology), and Bcl-2 (124 Mouse mAb, \#15071, 1:1000, Cell Signaling Technology). The PVDF membrane was rinsed with TBS-T buffer $(1 \times)$, and treated with secondary antibodies (Anti-mouse IgG, HRP-linked Antibody, \#7076, 1:10,000; Cell Signaling Technology or Anti-rabbit IgG, HRP-linked Antibody, \#7074, 1:10,000; Cell Signaling Technology) dissolved in Can Get Signal Immunoreaction Enhancer Solution 2 (TOYOBO) at $28^{\circ} \mathrm{C}$ for $1 \mathrm{~h}$. Finally, the PVDF membrane was reacted with ECL Prime Western Blotting Detection Reagents (GE Healthcare, Boston, MA, USA), and detected using the LAS-3000 luminescent image analyzer (FUJIFILM, Tokyo, Japan).

\subsection{Detection of Mitochondrial Membrane Potential}

Mitochondrial membrane potential was assayed using the JC-1 MitoMP Detection Kit (DOJINDO, Kumamoto, Japan). SBC-3 cells $\left(5 \times 10^{5}\right.$ cells $\left./ \mathrm{mL}\right)$ were seeded into a 6-well flat-bottomed plate. SBC-3 cells were treated with either $\mathrm{EtOH} / \mathrm{H}_{2} \mathrm{O}$ (1:1) (control), $10 \mu \mathrm{M}$ of cisplatin, or $10 \mu \mathrm{M}$ of $\mathbf{1}$. After $24 \mathrm{~h}$ of incubation, SBC-3 cells were detached using TrypLE Select and stained with JC- 1 dye at $37^{\circ} \mathrm{C}$ for 45 min according to the manufacturer's protocol. Flow cytometry analysis was performed using a BD FACSCelesta flow cytometer.

\subsection{Measurment of ROS Level}

The ROS generation assay was performed using the CellROX Green Flow Cytometer Assay Kit (Thermo Fisher Scientific). SBC-3 cells $\left(5 \times 10^{5}\right.$ cells $\left./ \mathrm{mL}\right)$ were cultured in a 6-well flat-bottomed plate and preincubated for $24 \mathrm{~h}$. Then, SBC-3 cells were treated with either $\mathrm{EtOH} / \mathrm{H}_{2} \mathrm{O}$ (1:1) (control), $2.5 \mathrm{mM}$ of NAC, $100 \mu \mathrm{M}$ of TBHP, or $10 \mu \mathrm{M}$ of $\mathbf{1}$ for $24 \mathrm{~h}$. SBC-3 cells were detached using TrypLE Select and stained with CellROX Green reagent at $37^{\circ} \mathrm{C}$ for $1 \mathrm{~h}$ according to the manufacturer's protocol. ROS levels were measured using a BD FACSCelesta flow cytometer.

\subsection{Mitophagy Detection}

Mitophagy detection was performed using the Mitophagy Detection Kit (DOJINDO). SBC-3 cells $\left(5 \times 10^{5}\right.$ cells $\left./ \mathrm{mL}\right)$ were seeded into a 6-well flat-bottomed plate. After preincubation, SBC-3 cells were washed with Hank's balanced salt solution (HBSS; 1x, Gibco) and treated with $100 \mathrm{nM}$ Mtphagy Dye at $37^{\circ} \mathrm{C}$ for $30 \mathrm{~min}$. Then, SBC-3 cells were rinsed with HBSS and treated with either $\mathrm{EtOH} / \mathrm{H}_{2} \mathrm{O}$ (1:1) (control), $7.5 \mu \mathrm{M}$ of CCCP, or $10 \mu \mathrm{M}$ of 1 for $24 \mathrm{~h}$. After the supernatant was removed and SBC-3 cells were washed with HBSS, the cells were incubated with $1 \mu \mathrm{M}$ Lyso Dye at $37^{\circ} \mathrm{C}$ for $30 \mathrm{~min}$ and observed using a BZ-X710 All-in-One Fluorescence Microscope (KEYENCE, Osaka, Japan).

\subsection{Statistical Analysis}

Statistical analysis was conducted using a one-way analysis of variance (ANOVA) followed by Dunnett's test. A probability $(p)$ value of less than 0.001 or 0.01 was distinguished to represent a statistically significant difference.

\section{Conclusions}

In this study, the chemical constituents of $S$. officinalis seeds were investigated, and 17 oleanane-type triterpene glycosides (1-17), including seven (1-7) previously unreported compounds, were isolated and identified. Compounds 1-5, 9, and 10 showed cytotoxicity 
against HL-60 cells, A549 cells, and SBC-3 cells with $\mathrm{IC}_{50}$ values in the range of $0.57-21 \mu \mathrm{M}$. The cytotoxicities of 1, 4, and 10 toward HL-60 cells and SBC-3 cells were almost as potent as that of cisplatin. Compound 1, a bisdesmosidic triterpene glycoside obtained in good yield, arrested the cell cycle of SBC-3 cells at the $\mathrm{G}_{2} / \mathrm{M}$ phase, and induced apoptosis through an intrinsic pathway; activation of caspase- $8,-9$, and -3 , cleavage of PARP, reduction in the Bcl-2/Bax ratio, depolarization of mitochondrial membrane potential, and ROS generation were observed after treatment of SBC-3 cells with 1 . As a result of mitochondrial dysfunction induced by $\mathbf{1}$, mitochondrial selective autophagy, termed mitophagy, occurred in SBC-3 cells. Compound $\mathbf{1}$ is a potential hit compound for the development of drugs against small-cell lung cancer.

Supplementary Materials: The following are available online: https:/ /www.mdpi.com/article/10.3 390/ijms23042047/s1.

Author Contributions: N.T., T.I., M.K. and Y.M. conceived and designed the experiments; N.T., T.I., M.K. and M.M. performed the experiments; T.I. and Y.M. wrote the paper. All authors have read and agreed to the published version of the manuscript.

Funding: This research received no external funding.

Conflicts of Interest: The authors declare no conflict of interest.

\section{References}

1. Yokosuka, A.; Takayama, H.; Mimaki, Y. Triterpene glycosides from the seeds of Dolichos lablab. Chem. Pharm. Bull. 2019, 67, 604-608. [CrossRef] [PubMed]

2. Yokosuka, A.; Okabe, G.; Tatsuno, S.; Mimaki, Y. Stryphnosides G-P, 10 new triterpene glycosides from the pericarps of Stryphnodendron fissuratum. Carbohydr. Res. 2016, 434, 18-26. [CrossRef] [PubMed]

3. Watanabe, K.; Mimaki, Y.; Fukaya, H.; Matsuo, Y. Cycloartane and oleanane glycosides from the tubers of Eranthis cilicica. Molecules 2019, 24, 69. [CrossRef] [PubMed]

4. Jitsuno, M.; Mimaki, Y. Triterpene glycosides from the aerial parts of Larrea tridentata. Phytochemistry 2010, 71, 2157-2167. [CrossRef] [PubMed]

5. Yokosuka, A.; Sano, T.; Hashimoto, K.; Sakagami, H.; Mimaki, Y. Triterpene glycosides from the whole plants of Anemone hupehensis var. japonica and their cytotoxic activity. Chem. Pharm. Bull. 2009, 57, 1425-1430. [CrossRef] [PubMed]

6. Matsuo, Y.; Watanabe, K.; Mimaki, Y. Triterpene glycosides from the underground parts of Caulophyllum thalictroides. J. Nat. Prod. 2009, 72, 1155-1160. [CrossRef]

7. Mimaki, Y.; Yokosuka, A.; Hamanaka, M.; Sakuma, C.; Yamori, T.; Sashida, Y. Triterpene saponins from the roots of Clematis chinensis. J. Nat. Prod. 2004, 67, 1511-1516. [CrossRef]

8. Tsukamoto, Y. (Ed.) The Grand Dictionary of Horticulture; Shogakukan: Tokyo, Japan, 1989; Volume 2, pp. $475-476$.

9. Hotta, M.; Ogata, K.; Nitta, A.; Hoshikawa, K.; Yanagi, M.; Yamazaki, K. (Eds.) Useful Plants of the World; Heibonnsha: Tokyo, Japan, 1996; p. 952.

10. Wichtl, M. (Ed.) Herbal Drugs and Phytopharmaceuticals; CRC Press: Boca Raton, FL, USA, 1994; pp. $453-454$.

11. Moniuszko-Szajwaj, B.; Masullo, M.; Kowalczyk, M.; Pecio, Ł.; Szumacher-Strabel, M.; Cieślak, A.; Piacente, S.; Oleszek, W.; Stochmal, A. Highly polar triterpenoid saponins from the roots of Saponaria officinalis L. Helv. Chim. Acta 2016, 99, 347-354. [CrossRef]

12. Lu, Y.; Van, D.; Deibert, L.; Bishop, G.; Balsevich, J. Antiproliferative quillaic acid and gypsogenin saponins from Saponaria officinalis L. roots. Phytochemistry 2015, 113, 108-120. [CrossRef]

13. Moniuszko-Szajwaj, B.; Pecio, Ł.; Kowalczyk, M.; Simonet, M.A.; Macias, A.F.; Szumacher-Strabel, M.; Cieślak, A.; Oleszek, W.; Stochmal, A. New triterpenoid saponins from the roots of Saponaria officinalis. Nat. Prod. Commun. 2013, 8, 1687-1690. [CrossRef]

14. Koike, K.; Jia, Z.; Nikaido, T. New triterpenoid saponins and sapogenins from Saponaria officinalis. J. Nat. Prod. 1999, 62, 1655-1659. [CrossRef] [PubMed]

15. Jia, Z.; Koike, K.; Nikaido, T. Saponarioside C, the first $\alpha$-D-galactose containing triterpenoid saponin, and five related compounds from Saponaria officinalis. J. Nat. Prod. 1999, 62, 449-453. [CrossRef] [PubMed]

16. Jia, Z.; Koike, K.; Nikaido, T. Major triterpenoid saponins from Saponaria officinalis. J. Nat. Prod. 1998, 61, 1368-1373. [CrossRef] [PubMed]

17. Ito, Y.; Miyashiro, I.; Ito, H.; Hosono, S.; Chihara, D.; Nakata-Yamada, K.; Nakayama, M.; Matsuzaka, M.; Hattori, M.; Sugiyama, H.; et al. Long-term survival and conditional survival of cancer patients in Japan using population-based cancer registry data. Cancer Sci. 2014, 105, 1480-1486. [CrossRef]

18. Larhsini, M.; Marston, A.; Hostettmann, K. Triterpenoid saponins from the roots of Silene cucubalus. Fitoterapia 2003, 74, $237-241$. [CrossRef] 
19. Guo, S.; Falk, E.; Kenne, L.; Rönnberg, B.; Sundquist, G.B. Triterpenoid saponins containing an acetylated branched D-fucosyl residue from Quillaja saponaria Molina. Phytochemistry 2000, 53, 861-868. [CrossRef]

20. Elgamal, A.H.M.; Soliman, M.S.H.; Karawya, S.M.; Mikhova, B.; Duddeck, H. Isolation of triterpene saponins from Gypsophila capillaris. Phytochemistry 1995, 38, 1481-1485. [CrossRef]

21. Morita, H.; Yun, S.Y.; Takeya, K.; Itokawa, H.; Yamada, K.; Shirota, O. Vaccaroid A, a new triterpenoid saponin with contractility of rat uterine from Vaccaria segetalis. Bioorg. Med. Chem. Lett. 1997, 7, 1095-1096. [CrossRef]

22. Koike, K.; Jia, Z.; Nikaido, T. Triterpenoid saponins from Vaccaria segetalis. Phytochemistry 1998, 47, 1343-1349. [CrossRef]

23. Sang, M.S.; Zou, L.M.; Lao, N.A.; Chen, L.Z.; Uzawa, J.; Fujimoto, Y. A new triterpenoid saponin from the seeds of Vaccaria segetalis. Chin. Chem. Lett. 2000, 11, 49-53.

24. Postel, R.; Fuchs, H. Improved Cell-Targeting Binding Molecule. International Publication No. WO 2020/126627 A1, 25 June 2020.

25. Mcllwain, D.R.; Berger, T.; Mak, W.T. Caspase function in cell death and disease. Cold Spring Harb. Perspect. Biol. 2013, 5, a008656. [CrossRef] [PubMed]

26. Morales, C.J.; Li, L.; Fattah, J.F.; Dong, Y.; Bey, A.E.; Patel, M.; Gao, J.; Boothman, A.D. Review of poly (ADP-ribose) polymerase (PARP) mechanism of action and rationale for targeting in cancer and other diseases. Crit. Rev. Eukaryot. Gene Expr. 2014, 24, 15-28. [CrossRef] [PubMed]

27. Eeva, J.; Nuutinen, U.; Ropponen, A.; Mättö, M.; Eray, M.; Pellinen, R.; Wahlfors, J.; Pelkonen, J. The involvement of mitochondria and the caspase-9 activation pathway in rituximab-induced apoptosis in FL cells. Apoptosis 2009, 14, 687-698. [CrossRef] [PubMed]

28. Pena-Blanco, A.; Garcia-Saez, A. Bax, Bak and beyond-mitochondrial performance in apoptosis. FEBS J. 2018, $285,416-431$. [CrossRef]

29. Circu, L.M.; Aw, Y.T. Reactive oxygen species, cellular redox systems, and apoptosis. Free Radic. Biol. Med. 2010, 48, 749-762. [CrossRef]

30. Bates-Averill, A.D.; Redza-Dutordoir, M. Activation of apoptosis signaling pathway by reactive oxygen species. Biochim. Biophys. Acta 2016, 1863, 2977-2992.

31. Stergiou, E.I.; Kapsogeorgou, K.E. Autophagy and metabolism in normal and malignant hematopoiesis. Int. J. Mol. Sci. 2021, 22, 8540. [CrossRef]

32. Wang, Y.; Nartiss, Y.; Steipe, B.; McQuibban, A.; Kim, K.P. ROS-induced mitochondrial depolarization initiates PARK2/PARKINdependent mitochondrial degradation by autophagy. Autophagy 2012, 8, 1462-1476. [CrossRef]

33. Xiao, B.; Goh, Y.J.; Xiao, L.; Xian, H.; Lim, L.K.; Liou, C.Y. Reactive oxygen species trigger Parkin/PINK1 pathway-dependent mitophagy by inducing mitochondrial recruitment of Parkin. J. Biol. Chem. 2017, 292, 16697-16708. [CrossRef]

34. Castrejón-Jiménez, S.N.; Leyva-Paredes, K.; Baltierra-Uribe, L.S.; Castillo-Cruz, J.; Campillo-Navarro, M.; Hernández-Pérez, D.A.; Luna-Angulo, B.A.; Chacón-Salinas, R.; Coral-Vázquez, M.R.; Estrada-García, I.; et al. Ursolic and Oleanolic Acids Induce Mitophagy in A549 Human Lung Cancer Cells. Molecules 2019, 24, 3444. [CrossRef] 